\title{
AEROSOL PROPERTIES OF MINERAL DUST AND ITS MIXTURES IN A REGIONAL
} BACKGROUND OF NORTH-CENTRAL IBERIAN PENINSULA

\author{
M. A. Burgos, D. Mateos, V. E. Cachorro*, C. Toledano, A. M. de Frutos
}

Grupo de Óptica Atmosférica, Universidad de Valladolid, Paseo Belén 7, CP 47011, Valladolid, Spain

* Corresponding author: chiqui@goa.uva.es

\section{Abstract (300 words)}

To broaden the knowledge about desert dust (DD) aerosols in western Mediterranean Basin, their fingerprints on optical and microphysical properties are analyzed during DD episodes in the northcentral plateau of the Iberian Peninsula between 2003 and 2014. Aerosol columnar properties obtained from the AErosol RObotic NETwork (AERONET), such as aerosol optical depth (AOD), Ångström exponent (AE), volume particle size distribution, volume concentration (VC), sphericity, single scattering albedo, among others, are analyzed in order to provide a general characterization, being some of them compared to particle mass surface concentrations $\mathrm{PM}_{10}, \mathrm{PM}_{2.5}$, and their ratio, data obtained from EMEP network. The mean intensity of DD episodes exhibits: $\mathrm{AOD}_{440 \mathrm{~nm}}=0.27 \pm 0.12, \mathrm{PM}_{10}=$ $24 \pm 18 \mu \mathrm{g} / \mathrm{m}^{3}, \mathrm{AE}=0.94 \pm 0.40$ and $\mathrm{PM}_{2.5} / \mathrm{PM}_{10}=0.54 \pm 0.16$. The $\mathrm{AOD}$ and $\mathrm{PM}_{10}$ annual cycles show maximum intensity in March and summer and minima in winter. A customized threshold of $\mathrm{AE}=1$ distinguishes two types of dusty days, those with a prevailing desert character and those of mixed type, which is corroborated by sphericity values. Three well established intervals are obtained with the fine mode volume fraction $\left(\mathrm{VC}_{\mathrm{F}} / \mathrm{VC}_{\mathrm{T}}\right)$. Coarse-mode-dominated cases $\left(\mathrm{VC}_{\mathrm{F}} / \mathrm{VC}_{\mathrm{T}} \leq 0.2\right)$ present a mineral dust character: e.g., particle maximum concentration about $2 \mu \mathrm{m}$, non-sphericity, stronger absorption power at shorter wavelengths, among others. The relevance of the fine mode is noticeable in mixtures with a predominance of particles about $0.2-0.3 \mu \mathrm{m}$ radii. Conditions characterized by $0.2<\mathrm{VC}_{\mathrm{F}} / \mathrm{VC}_{\mathrm{T}}<0.45$ and $\mathrm{VC}_{\mathrm{F}} / \mathrm{VC}_{\mathrm{T}} \geq 0.45$ present a larger variability in all investigated aerosol properties. Relationships between AOD and columnar particle volume concentration give volume extinction efficiencies between 1.7 and $3.7 \mu \mathrm{m}^{2} / \mu \mathrm{m}^{3}$ depending on $\mathrm{VC}_{\mathrm{F}} / \mathrm{VC}_{\mathrm{T}}$. Aerosol scale height is obtained from relationships between surface and columnar concentrations displaying very large values up to $10 \mathrm{~km}$. The uncertainty associated with the transformation between AOD and $\mathrm{PM}_{10}$ can be partially reduced when the aerosol microphysical properties are known. 


\section{Introduction}

Airborne dust is a key player in the atmospheric science studies since it is considered to impact climate, air quality and human health by causing respiratory diseases and infections or even certain epidemics; Earth's radiative budget by scattering/absorbing solar radiation; life cloud cycle acting as cloud condensation nuclei or ice nuclei; air visibility that can affect traffic or military operations; different continental and maritime ecosystems by changing the provided nutrients; and the soil erosion in agriculture (e.g., Horvath et al., 1998; Dubovik et al., 2002; Eck et al., 2010; Yannopoulos et al., 2015; Gkikas et al., 2013; Knippertz and Stuut, 2014). Mineral dust accounts for $13 \%$ of the total natural emissions in the Earth's system (e.g., Viana et al., 2014), being the Sahara and Sahel deserts the most relevant natural sources of crustal aerosols in the Northern Hemisphere (Prospero et al., 2002) with more than $200 \mathrm{Tg}$ per year emitted to the atmosphere and transported over the Atlantic Ocean (Kaufmann et al., 2005). The injection of desert dust (DD) into the atmosphere from the Sahara's two major dust sources (Bodélé depression and eastern Mauritania) by different re-suspension processes can achieve high atmospheric layers, being responsible for high aerosol loads that are transported very large distances, to the northern Atlantic Ocean, Caribbean Sea, Amazon Basin, Mediterranean Basin, and European continent (e.g., Goudie and Middleton, 2001).

Focusing on the studies devoted to the analysis of DD over the Iberian Peninsula (IP), it has been observed that different areas exhibit different behavior and annual cycle of DD events because of the orography and the uneven synoptic conditions along the IP (Toledano et al., 2007; Obregón et al., 2015; Mateos et al., 2014). The closeness of the IP to the African continent enhances the impact of these high turbidity events on different aspects. For example, DD outbreaks impact on air quality by increasing aerosol load, being the main responsible of the daily exceedances over $50 \mu \mathrm{g} \mathrm{m}^{-3}$ (limit established by the 2008/50/EC European Directive) in the particulate matter $\left(\mathrm{PM}_{10}\right)$ levels (e.g., Escudero et al., 2007; Querol et al., 2014; Salvador et al., 2013, 2014). This is reinforced by long residence times of dust particles in the atmosphere favored by the low precipitation levels (e.g., Escudero et al., 2005; Cabello et al., 2012). Moreover, aerosol seasonal patterns are modulated by mineral dust producing two maxima along the year of PM or aerosol optical depth (AOD) in certain areas of the IP (e.g., Mateos et al., 2015). The DD aerosols also present influence on the radiative budget with an aerosol forcing efficiency about $-70 \mathrm{Wm}^{-2}$ at the surface in south-eastern IP (Valenzuela et al., 2014). Acute effects on human health also occur during DD events in Spain, accelerating cardiovascular and respiratory mortality (Pérez et al., 2012; Reyes et al., 2014). 
Different methodologies have been recently developed in order to detect and identify DD intrusions by means of $\mathrm{PM}_{\mathrm{x}}$ (x refers here to the upper particle cut-off) or AOD data. Likewise, other tools are used to identify DD outbreaks, such as aerosol model forecasts, air mass back trajectories, satellite images, among others (e.g., Pace et al., 2006; Tafuro et al., 2006; Escudero et al., 2007; Toledano et al., 2007; Querol et al., 2009; Cabello et al., 2012; Pey et al., 2013; Salvador et al., 2014; and Cachorro et al., 2016). All these tools can be used in very different and combined ways in order to carry out the DD detection and the evaluation of its occurrence, intensity and impact, as for example over the entire Mediterranean Basin.

An extensive work about desert dust studies has been carried out during the last years in the Mediterranean area. Pace et al., (2006) and Meloni et al., (2007) obtained occurrence maxima in May and July in the Lampedusa island (Central Mediterranean) using MFRSR measurements and air mass backward trajectories in the DD detection. A summer maximum (June and August) is reported by Toledano et al., (2007) in south-western Spain by a combination of Sun photometer data and backtrajectory analysis of air mass origin. Valenzuela et al., (2012) reported the maximum of annual occurrence in July over south-eastern Spain by analyzing air mass back trajectories. Pey et al., (2013) obtained a shifted annual maximum from April to July between eastern and western Mediterranean Basin in the 2000s using $\mathrm{PM}_{\mathrm{x}}$ surface data and a combination of meteorological products, aerosol maps, satellite images and air mass back-trajectories. Cachorro et al., (2016) obtained an annual cycle of dusty day occurrence over north-central IP of similar characteristics to that reported by Salvador et al. (2013) for Madrid area, but with lower occurrence.

The application of the mentioned methodologies for DD detection allows further characterization studies, which are related to the evaluation of the different properties that define DD aerosols. However, only some of these properties are used in the methodology of DD identification. In our case, columnar AOD and Ångström exponent (AE), and surface $\mathrm{PM}_{10}$ concentration are used for detection. These quantities will be characterized in the present study, together with other properties, such as volume particle size distribution (VPSD), asymmetry parameter (g) or single scattering albedo (SSA).

Previous studies in the African surroundings have shown that mineral dust aerosols are dominated by large particles beyond $0.6 \mu \mathrm{m}$, and they exhibit non-sphericity and a pronounced absorption in the blue spectral range, among others (e.g., Dubovik et al., 2002; Eck et al., 2010; Giles et al., 2012). These are however the expected properties for pure dust near the sources. The dust over our study region has experienced long-range transport, with possible apportioning of other aerosol particles as well as mixture with local aerosol. So it is to expect that some variability and differences with respect to pure dust properties are found in the intensive properties. 
The aerosol characterization developed in this article is based on a DD inventory previously reported by Cachorro et al. (2016). This inventory is composed by DD event days occurring in the north-central area of the Iberian Peninsula between January 2003 and December 2014. The methodology behind the inventory simultaneously uses columnar and surface aerosol data to identify DD events. Once the DD fingerprint is recognized in one or both of these core variables, a thorough manual inspection of the data is carried out together with the analysis of air mass backward trajectories, meteorological maps, satellite images, and model forecasts, in order to corroborate the right classification of each DD outbreak.

As a natural continuation of the inventory analysis, the aim of this study is to carry out the characterization of the main optical and microphysical properties during mineral dust events, for a better understanding of mineral aerosol over the IP. One of the most interesting results reported by Cachorro et al. (2016) is the analysis of the two sub-groups of DD aerosols, one labeled as desert (D) and the other one labeled as mixed-desert (MD). These groups were discriminated by means of the Ångström exponent. Such kind of study is required in those areas where aerosol mixtures play a non-negligible role caused by different reasons (large distance to the sources, orography, presence of big industrial cities or other aerosol types, among others) and where the DD identification is complicated since the boundaries among well-known (pure) aerosol types are ambiguous.

A detailed analysis of the aerosol surface concentration and columnar optical and microphysical properties is carried out here using EMEP (European Monitoring and Evaluation Programme) and AERONET (AErosol RObotic NETwork, Holben et al., 1998) observations. These data allow the study about how columnar and surface quantities are related. Relationship between different size parameters are studied, like $\mathrm{AE}$, effective radius (ER), the fraction of the fine mode volume concentration $\left(\mathrm{VC}_{\mathrm{F}} / \mathrm{VC}_{\mathrm{T}}\right)$ and surface $\mathrm{PM}_{2.5} / \mathrm{PM}_{10}$ ratio. Relationships between columnar volume concentrations and aerosol loads by columnar AOD and surface $\mathrm{PM}_{\mathrm{x}}$ are also reported to better define their validity during high turbidity dust events as one of the most relevant results. To the best of our knowledge, some of these relationships are established for the first time. Finally, radiative quantities are also investigated to provide a general insight about absorbing and scattering properties: sphericity fraction, single scattering albedo and asymmetry factor during DD events. Hence, this is the first DD aerosol characterization based on a long-term inventory with emphasis on the relationship between columnar and surface properties.

\section{Desert Dust Inventory: sites, databases and method}

\subsection{Sites and databases}

The monitoring sites for the columnar and surface properties are placed in "Castilla y León" region, covering the north-central part of the Iberian Peninsula in an elevated plateau ( $\sim 800 \mathrm{~m}$ a.s.l., called 
"Meseta Central"), surrounded by three mountain systems in the north, south and east. These large landforms (up to $2500 \mathrm{~m}$ a.s.l.) make it difficult the arrival of air masses from southern areas. The study area exhibits a clean continental aerosol background, isolated from any large urban or industrial centres, which implies that aerosol observations are representative of the whole region. The detection of moderate or even minor DD aerosol intrusions is possible since they notably modify the background properties.

Columnar aerosol data measured by CIMEL CE-318 (Holben et al., 1998) Sun photometers from AERONET contains instantaneous values of spectral AOD (at 7 different wavelengths) and its associated Ångström exponent (AE) at Palencia site $\left(41.9^{\circ} \mathrm{N}, 4.5^{\circ} \mathrm{W}\right.$, and $750 \mathrm{~m}$ a.s.1.), which are completed with the nearby Autilla site $\left(41.9^{\circ} \mathrm{N}, 4.6^{\circ} \mathrm{W}\right.$, and $870 \mathrm{~m}$ a.s.1., $7 \mathrm{~km}$ away) when gaps appear in the database. The Sun photometer performs direct sun measurements every 15 minutes during daytime. The AOD at 440nm wavelength is selected in this study to perform the DD characterization. Furthermore, the CIMEL instrument hourly measures sky radiances, both in almucantar and principal plane geometries, at 440, 670, 870, and $1020 \mathrm{~nm}$ wavelengths. Table 1 summarizes the aerosol properties used in this study. Further details about the inversion algorithm were deeply described by, e.g., Dubovik et al. (2000; 2006), Holben et al., (2006), and Eck et al. (2008). All the instantaneous columnar aerosol data are daily averaged in the characterization presented in this study. As can be seen in Table 1, a notable reduction in the number of inversion products compared to AOD is due to the fewer radiance measurement sampling and the quality constraints imposed by AERONET inversion algorithm.

The closest site to Palencia with measurements of aerosol surface concentrations ( $\mathrm{PM}_{10}$ and $\left.\mathrm{PM}_{2.5}\right)$ belonging to EMEP network is located in Peñausende (41.28 $\mathrm{N}, 5.87^{\circ} \mathrm{W}$, and $985 \mathrm{~m}$ a.s.1.). These $\mathrm{PM}_{10}$ and $\mathrm{PM}_{2.5}$ concentrations are obtained daily by gravimetric determinations. These are the official data reported to the European Commission and their high quality is guaranteed (e.g., Pey et al., 2013). The $\mathrm{PM}$ ratio $\left(\mathrm{PM}_{2.5} / \mathrm{PM}_{10}\right)$ gives also an idea of the predominance of fine (large ratio) or coarse (low ratio) particle modes.

Apart from the conceptual differences between columnar and surface aerosol load represented by AOD and $\mathrm{PM}_{\mathrm{x}}$, there exist some significant differences in relation with the sampling of both aerosol concentration measurements. The CIMEL Sun photometer measures nearly instantaneous data under clear-sky conditions during daytime, whereas $\mathrm{PM}_{\mathrm{x}}$ data give surface information integrated over 24 hours under all sky conditions. Details and discussion about the AOD-AE and $\mathrm{PM}_{\mathrm{x}}$ measurements and their sampling can be seen in Bennouna et al. (2016). 
Table 1. Information on the columnar and surface quantities used in this study. ND is the number of days with available data into the DD dataset (a total of 418 days in 2003-2014).

\begin{tabular}{|c|c|c|c|c|c|}
\hline Network & Site & Quantities & $\begin{array}{c}\text { Time resolution used for } \\
\text { daily means }\end{array}$ & ND & + Info \\
\hline \multirow{4}{*}{ 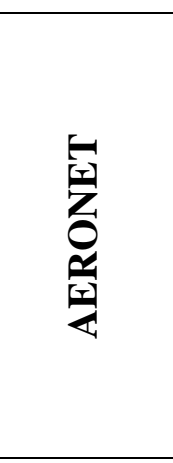 } & \multirow{4}{*}{$\begin{array}{c}\text { Palencia } \\
+ \\
\text { Autilla }\end{array}$} & $\mathrm{AOD}, \mathrm{AE}$ & $15-\min$ & 324 & Level 2.0 \\
\hline & & $\begin{array}{c}\mathrm{VPSD} \\
\mathrm{ER}_{\mathrm{T} / \mathrm{F} / \mathrm{C}} \\
\mathrm{VC}_{\mathrm{T} / \mathrm{F} / \mathrm{C}} \\
\end{array}$ & $1 \mathrm{~h}$ & 182 & Level $1.5+$ other criteria ${ }^{a}$ \\
\hline & & Sphericity & $1 \mathrm{~h}$ & 122 & $\begin{aligned} & \text { Level } 1.5 \\
+ & \text { other criteria }^{\mathrm{b}}\end{aligned}$ \\
\hline & & SSA, g & $1 \mathrm{~h}$ & 163 & $\begin{aligned} & \text { Level } 1.5 \\
&+ \text { other criteria }^{c} \\
&\end{aligned}$ \\
\hline$\sum_{\text {동 }}^{0}$ & Peñausende & $\begin{array}{c}\mathrm{PM}_{10} \\
\mathrm{PM}_{2.5} \\
\mathrm{PM}_{2.5} / \mathrm{PM}_{10}\end{array}$ & $24 \mathrm{~h}$ & $\begin{array}{l}399 \\
403 \\
387\end{array}$ & $\begin{array}{l}\mathrm{PM}_{10} \text { and } \mathrm{PM}_{2.5} \text { obtained } \\
\text { from different filters }\end{array}$ \\
\hline
\end{tabular}

a) same AERONET level 2.0 criteria (solar zenith angle $>50^{\circ}$, number of symmetrical angles, and sky

error between $5 \%$ and $8 \%$ depending on AOD), but there is no filter with respect to AOD; b) same AERONET level 2.0 criteria but with AOD $\geq 0.2$ (see Dubovik et al., 2006); c) same AERONET level 2.0 criteria but with AOD $\geq 0.15$ (see Mallet et al., 2013; Mateos et al., 2014).

\subsection{Methodology}

The employed methodology for desert outbreak identification based on columnar and surface aerosol data $\left(\mathrm{AOD} / \mathrm{AE} / \mathrm{PM}_{10}\right)$ is explained in detail by Cachorro et al. (2016) and therefore only a short description is provided here. A set of thresholds for AOD (440nm) and $\mathrm{PM}_{10}\left(0.18\right.$ and $13 \mu \mathrm{g} \mathrm{m}^{-3}$, respectively) are selected taking into account a long-term statistical analysis. Moreover, other important ancillary information is also taken into account together with aerosol information: air mass backward trajectories, satellite images, meteorological maps and aerosol model forecasting, which are manually analysed. Therefore this methodology does not restrict DD events identification to those days with aerosol data. It is worth mentioning here that the DD inventory of dusty days is elaborated with instantaneous AOD data when available while the foregoing characterization is performed on a daily basis. The use of the instantaneous data allowed us to detect the sharp time when the intrusion arrives, although DD conditions are attributed to that day regardless the arrival time. Therefore, for those days showing the arrival of dust after midday, daily means can present slightly modified values with respect 
to the "expected" DD aerosol properties. These "non-typical" values have been thoroughly investigated in order to accurately accomplish the DD characterization.

The AE threshold to separate DD event days into two sub-groups is set to 1.0, since it corresponds to a typical value assigned to separate fine and coarse mode predominant aerosols (e.g, Toledano et al., 2007; Di Biagio et al., 2010; Guirado et al., 2014). Those days with mean AE values below 1.0 are noted as "D type". However, during Saharan dust intrusions, mixing with other aerosol types can occur, being DD aerosols a fraction of that mixture (with a wide range of concentrations), therefore the values of the aerosol properties may not be the ones expected for pure mineral dust (e.g., Pace et al., 2006; Tafuro et al., 2006; Basart et al., 2009; Eck et al., 2010). In our inventory, this category can be represented by $1<\mathrm{AE}<1.5$ and is indicated by MD type. It must be highlighted that "mixture" conditions mean the possible superposition of different aerosol layers located at different heights and loaded with different aerosol types. The measurements of the aerosol optical properties of the entire column take into account all such layers and, therefore, their values are not attributed to one specific aerosol type. Generally, a desert dust episode is composed of D and MD event days, because the majority of the detected DD episodes are of moderate intensity. The selection of criteria to differentiate between fine and coarse particle predominance is not an easy task due to the strong site dependency (local aerosol) and the variable characteristics of the DD events (origin and formation, the followed path, among others). Therefore, many different thresholds used by different authors worldwide can be found in the literature (e.g., Gkikas et al., 2016).

Overall, the number of DD event days is 418 for the 12-year period (2003-2014) according to the inventory described by Cachorro et al., (2016), but only 304 coincident days are available for AOD and $\mathrm{PM}_{10}$. Hence, the available DD database is reduced by almost $30 \%$ in the aerosol characterization study. The DD database contains 162 days of D type and 142 of MD type. Figure 1 shows daily aerosol loads for the two types together with the non-DD event days (a total of 2466) that comprise the whole database for both AOD (Figure 1a) and $\mathrm{PM}_{10}$ (Figure 1b) during the analyzed period. As it can be seen, dusty days represent $\sim 11 \%$ of the total. DD outbreaks are responsible for $45 \%$ of the moderate and highturbidity days showing AOD $>0.2$. This percentage increases up to $52 \%$ for those days with $\mathrm{PM}_{10}>20$ $\mu \mathrm{g} \mathrm{m}^{-3}$. The remaining percentage can be attributed to other high-turbidity episodes such as biomass burning or industrial aerosol. 

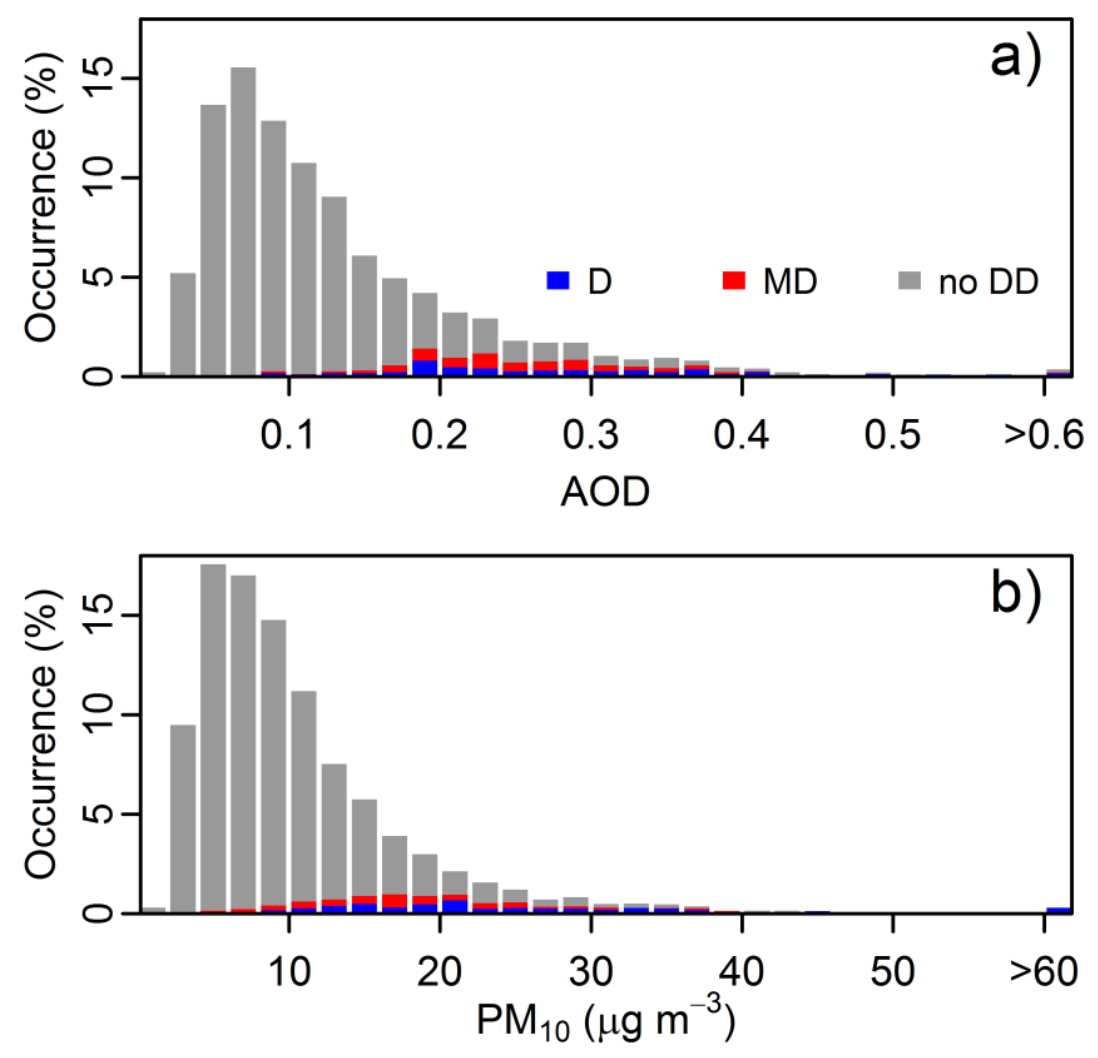

213 Figure 1. Frequency histograms of AOD (a), $\mathrm{PM}_{10}$ (b) during no DD (gray), D (blue), and MD (red) 214 event days in the period 2003-2014.

\section{Results and Discussion}

\subsection{Characteristics of AOD, $\mathrm{PM}_{10}, \mathrm{AE}$, and $\mathrm{PM}_{2.5} / \mathrm{PM}_{10}$ during DD events}

\subsubsection{Frequency histograms}

The frequency histograms of the daily values of $\mathrm{AOD}, \mathrm{PM}_{10}, \mathrm{AE}$, and $\mathrm{PM}_{2.5} / \mathrm{PM}_{10}$ for $\mathrm{D}$ and $\mathrm{MD}$ event days are shown in Figure 2. Aerosol load during the DD events presents most AOD daily values in 222 the range $0.15-0.35(\sim 72 \%)$ and between 15 and $35 \mu \mathrm{g} \mathrm{m}{ }^{-3}$ for $\mathrm{PM}_{10}(\sim 60 \%)$. The occurrence 223 frequency for AOD peaks in 0.2 for both subgroups and decreases forwards. A similar behavior is 224 observed for $\mathrm{PM}_{10}$ quantity with the maximum about 15-20 $\mu \mathrm{g} \mathrm{m}^{-3}$ depending on the category or 225 subgroup. The most intense events present $\mathrm{AOD}$ and $\mathrm{PM}_{10}$ mean values over 0.40 and $40 \mu \mathrm{g} \mathrm{m}^{-3}$, 226 respectively representing about $10 \%$ of the total dusty days. In particular, exceedances beyond $50 \mu \mathrm{g} \mathrm{m}^{-}$ $227{ }^{3}$, threshold established by the 2008/50/EC European Directive, are achieved in 19 cases or the $\sim 5 \%$ of 228 the total dusty days in the period 2003-2014. 

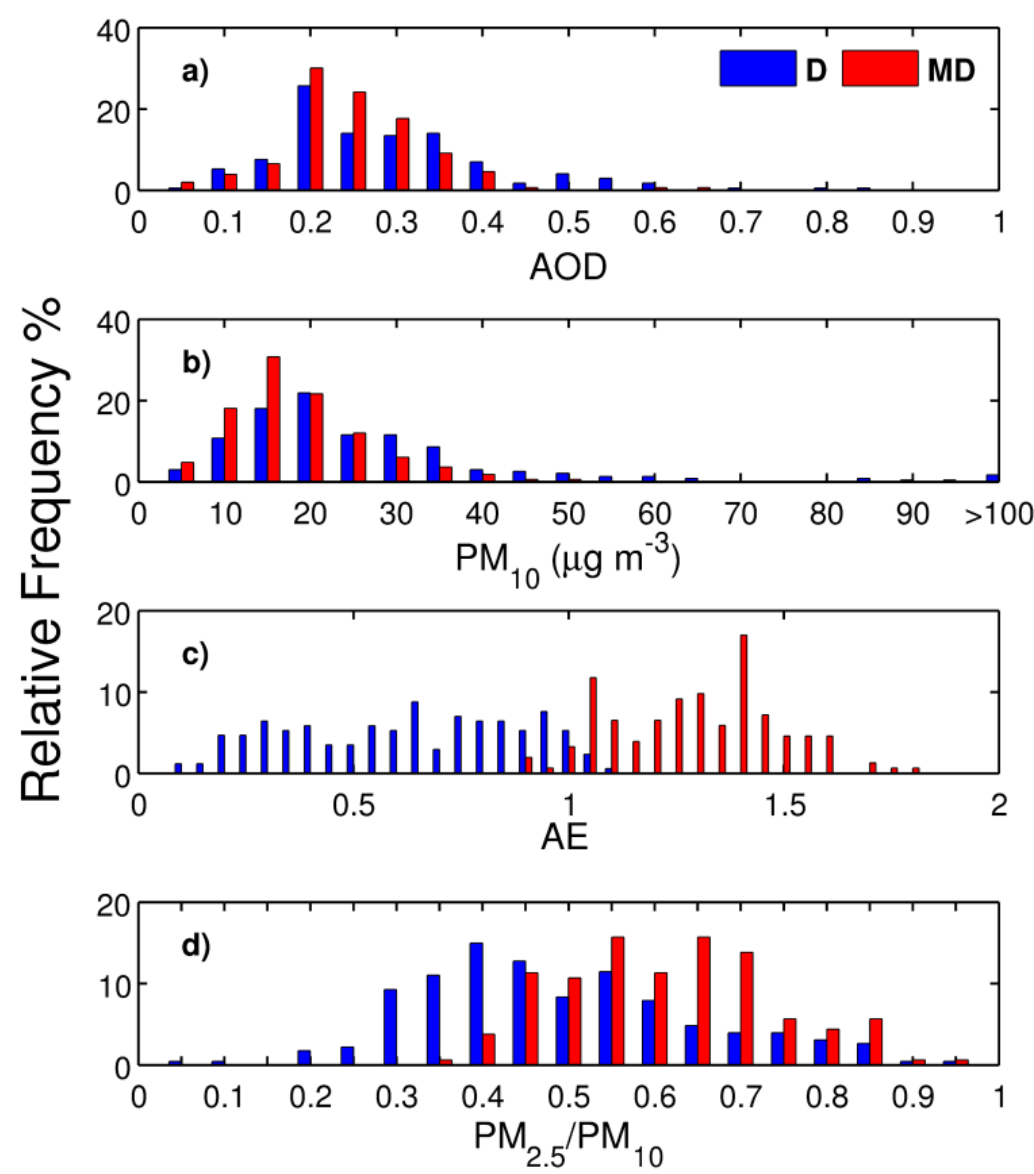

Figure 2. Frequency histograms of $\operatorname{AOD}(a), \mathrm{PM}_{10}\left(\mathrm{~b}\right.$, in $\left.\mu \mathrm{g} \mathrm{m} \mathrm{m}^{-3}\right), \mathrm{AE}$ (c), and $\mathrm{PM}_{2.5} / \mathrm{PM}_{10}$ (d) during D and MD event days in the period 2003-2014.

With respect to the aerosol size predominance, represented by the AE, Figure 2c illustrates the threshold values used for the discrimination between D and MD categories. Around $76 \%$ of AE values fall between 0.5 and 1.5, displaying an even distribution. The lowest $\mathrm{AE}$ values $(<0.5)$, that indicates strong coarse mode predominance, represent about $18 \%$ of the DD event days.

The $\mathrm{PM}_{2.5} / \mathrm{PM}_{10}$ is useful to complete the analysis since this is the only variable not (directly) used in the DD identification. The PM ratio values span from 0.1 to 0.95 , with most of the data concentrated in the range 0.4-0.7 ( 62\%). The extreme categories 0-0.4 and 0.7-1.0 present similar weight ( 19\%). The PM ratio frequencies considerably mix up D and MD categories, with a wider interval for D type.

Daily mean values out of the established thresholds (see Section 2) are registered due to two possible situations. On one hand, daily averages are considered in the characterization meanwhile the thresholds to detect a DD event day are established for the instantaneous AOD values within a day (as mentioned 
above). Thus, if an outbreak occurs after midday, it is possible to detect it thanks to the instantaneous values in spite of the fact that the daily mean does not overcome the corresponding threshold. On the other hand, the followed methodology allows identifying an outbreak when its impact is only visible at high layers or only at surface level, in which case only the AOD or $\mathrm{PM}_{10}$ quantity overcomes its established threshold. These cases highlight the advantage of this methodology. Overall the daily mean values out of the thresholds represent the $\sim 15 \%(\sim 18 \%)$ of the total event days for AOD $\left(\mathrm{PM}_{10}\right)$.

Table 2 briefly summarizes the statistics of $\mathrm{AOD}, \mathrm{PM}_{10}, \mathrm{AE}$, and $\mathrm{PM}_{2.5} / \mathrm{PM}_{10}$ quantities for desert dust intrusion days. Overall, DD outbreaks showing large aerosol loads rule the mean value since this statistical parameter stays above the median. However, this effect is weaker in the MD subset. The differences between mean and median values are generally larger for $\mathrm{PM}_{10}$ quantity than for AOD. This fact can be understood from the histograms shown in Figure 2, where surface aerosols present a wider interval, achieving concentrations above $100 \mu \mathrm{g} \mathrm{m}^{-3}$. However, $\mathrm{AE}$ and $\mathrm{PM}_{2.5} / \mathrm{PM}_{10}$ present very similar values of the mean and median, indicating a more even distribution of their data. The AOD, $\mathrm{PM}_{10}, \mathrm{AE}$, and $\mathrm{PM}_{2.5} / \mathrm{PM}_{10}$ data sets do not follow a normal distribution. The AOD and $\mathrm{PM}_{10}$ exhibit a log-normal shape (O’Neill et al., 2000), whereas $\mathrm{AE}$ and $\mathrm{PM}_{2.5} / \mathrm{PM}_{10}$ frequency distributions present platykurtic shapes. These behaviors are linked with the frequency histograms shown in Figure 2. The stronger loads and larger particles associated to D type are corroborated by the percentile values (larger P95 of AOD and $\mathrm{PM}_{10}$, and lower $\mathrm{P} 5$ of $\mathrm{AE}$ and $\mathrm{PM}_{2.5} / \mathrm{PM}_{10}$ ).

Table 2. Mean and standard deviation (SD), median and quartile deviation (QD), percentiles 5 (P5) and 95 (P95), maximum, skewness (s) and kurtosis (k) for AOD, $\mathrm{PM}_{10}$ (in $\mu \mathrm{g} \mathrm{m}^{-3}$ ), AE, and $\mathrm{PM}_{2.5} / \mathrm{PM}_{10}$ for each $\mathrm{D}, \mathrm{MD}$, and $\mathrm{D}+\mathrm{MD}$ event days.

\begin{tabular}{|c|c|c|c|c|c|c|c|c|}
\hline Event Days & Quantity & Mean \pm SD & Median $\pm Q D$ & P5 & $\mathbf{P 9 5}$ & Max. & $\mathbf{S}$ & $\mathbf{k}$ \\
\hline \multirow{4}{*}{$\mathrm{D}+\mathrm{MD}$} & AOD & $0.27 \pm 0.12$ & $0.25 \pm 0.07$ & 0.12 & 0.50 & 0.87 & 1.49 & 7.05 \\
\hline & $\mathbf{A E}$ & $0.94 \pm 0.41$ & $0.98 \pm 0.33$ & 0.25 & 1.54 & 1.82 & - & 2.02 \\
\hline & $\mathbf{P M}_{10}$ & $24 \pm 18$ & $20 \pm 7$ & 8 & 49 & 197 & 4.44 & 33.75 \\
\hline & $\mathbf{P M}_{2.5} / \mathbf{P M}_{10}$ & $0.54 \pm 0.16$ & $0.54 \pm 0.12$ & 0.31 & 0.82 & 0.94 & 0.07 & 2.62 \\
\hline \multirow{4}{*}{ D } & AOD & $0.29 \pm 0.13$ & $0.26 \pm 0.08$ & 0.11 & 0.54 & 0.87 & 1.31 & 5.61 \\
\hline & $\mathbf{A E}$ & $0.62 \pm 0.26$ & $0.63 \pm 0.23$ & 0.19 & 1.00 & 1.10 & - & 1.87 \\
\hline & $\mathbf{P M}_{10}$ & $27 \pm 22$ & $21 \pm 9$ & 8.15 & 60.55 & 197 & 3.80 & 24.16 \\
\hline & $\mathrm{PM}_{2.5} / \mathrm{PM}_{10}$ & $0.49 \pm 0.16$ & $0.46 \pm 0.11$ & 0.28 & 0.8 & 0.93 & 0.41 & 2.89 \\
\hline \multirow{4}{*}{ MD } & AOD & $0.25 \pm 0.09$ & $0.24 \pm 0.05$ & 0.12 & 0.38 & 0.65 & 1.07 & 6.89 \\
\hline & $\mathbf{A E}$ & $1.30 \pm 0.19$ & $1.32 \pm 0.14$ & 1.01 & 1.59 & 1.82 & 0.07 & 2.48 \\
\hline & $\mathbf{P M}_{10}$ & $18 \pm 8$ & $17 \pm 5$ & 7.8 & 36 & 50 & 1.04 & 4.51 \\
\hline & $\mathbf{P M}_{2.5} / \mathbf{P M}_{10}$ & $0.61 \pm 0.12$ & $0.63 \pm 0.14$ & 0.43 & 0.83 & 0.94 & 0.20 & 2.39 \\
\hline
\end{tabular}


269 Figure 3 shows the AE-AOD scatterplot for all daily means and dusty days including information 270 about the corresponding $\mathrm{PM}_{10}$ or $\mathrm{PM}_{2.5} / \mathrm{PM}_{10}$ values. In order to obtain a better visualization in Figure $2713 \mathrm{~b}$, an upper threshold of $40 \mu \mathrm{g} \mathrm{m}^{-3}$ has been established for $\mathrm{PM}_{10}$ values. The right identification of DD 272 events with the employed method is corroborated in Figure 3a, in which dusty days stand out among the 273 entire dataset. The shape of this diagram for D type is similar to that reported by the analysis of DD 274 aerosols performed in previous studies about nearby areas (e.g., Toledano et al., 2007; Di Biagio et al., 275 2010; Valenzuela et al., 2012; Obregón et al., 2015). The mixing of dust with other aerosol types 276 associated to MD type put the DD intrusions of this sub-group in the unexpected area $(\mathrm{AE}>1)$ of this 277 kind of diagram.

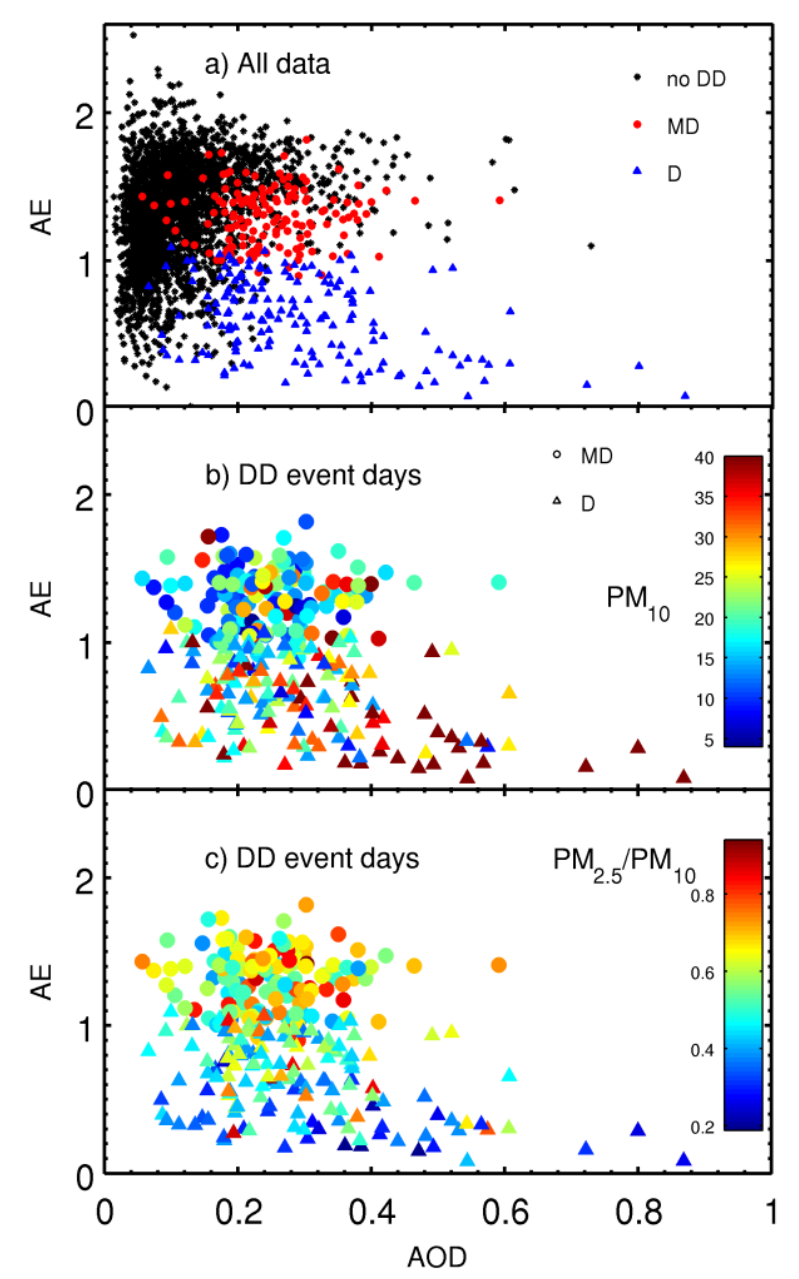

280 Figure 3. AE-AOD scatterplot for all data (a) and for DD intrusions (b,c), with the corresponding daily 281 value of $\mathrm{PM}_{10}$ (b) and $\mathrm{PM}_{2.5} / \mathrm{PM}_{10}$ (c) in colour scale. The two types of DD intrusions are represented by 282 triangles (D type) and circles (MD type). 
Previous studies have also stated that DD intrusions in the Mediterranean Basin can present moderate AOD values associated with large AE values (e.g., Pace et al., 2006; Tafuro et al., 2006). The same has been shown by Pey et al., (2013) when analyzing the intensity of DD outbreaks by $\mathrm{PM}_{\mathrm{x}}$ values for the whole Mediterranean basin. In order to analyze the intensity of the DD outbreaks and following the AOD criterion used by Gkikas et al. (2016), the mean plus four times standard deviation, our extreme DD events are those with an AOD larger than 0.5. This extreme subset represents 16 dusty days (about $5 \%$ of the total DD event days). Strong episodes, determined with the AOD interval between mean plus two and four times the standard deviation, range between 0.3 and 0.5 . There are 85 cases ( $26 \%$ of days). Finally, 223 days (69\%) are low-moderate DD outbreaks and exhibit an AOD below 0.3.

The relationships among AOD, AE and surface concentrations under DD intrusions display different behaviors (see Figures $3 \mathrm{~b}$ and $3 \mathrm{c}$ ). For the D subset, the four most intense columnar events (AOD > 0.7) are linked with large surface concentrations too $\left(\mathrm{PM}_{10}>40 \mu \mathrm{g} \mathrm{m}^{-3}\right)$, with a predominance of the coarse mode $\left(\mathrm{PM}_{2.5} / \mathrm{PM}_{10}<0.5\right.$ and $\left.\mathrm{AE}<0.6\right)$. For instance, Figure $4 \mathrm{~b}$ shows the time series of all the quantities during a strong event in October 2008: AOD values about 0.6 and a maximum PM $_{10}$ larger than $40 \mu \mathrm{g} \mathrm{m}^{-3}$. It is worth mentioning that during this episode, there was high temporal agreement between columnar and surface aerosol load, although the PM ratio only reached values close to 0.4 meanwhile AE was close to zero.

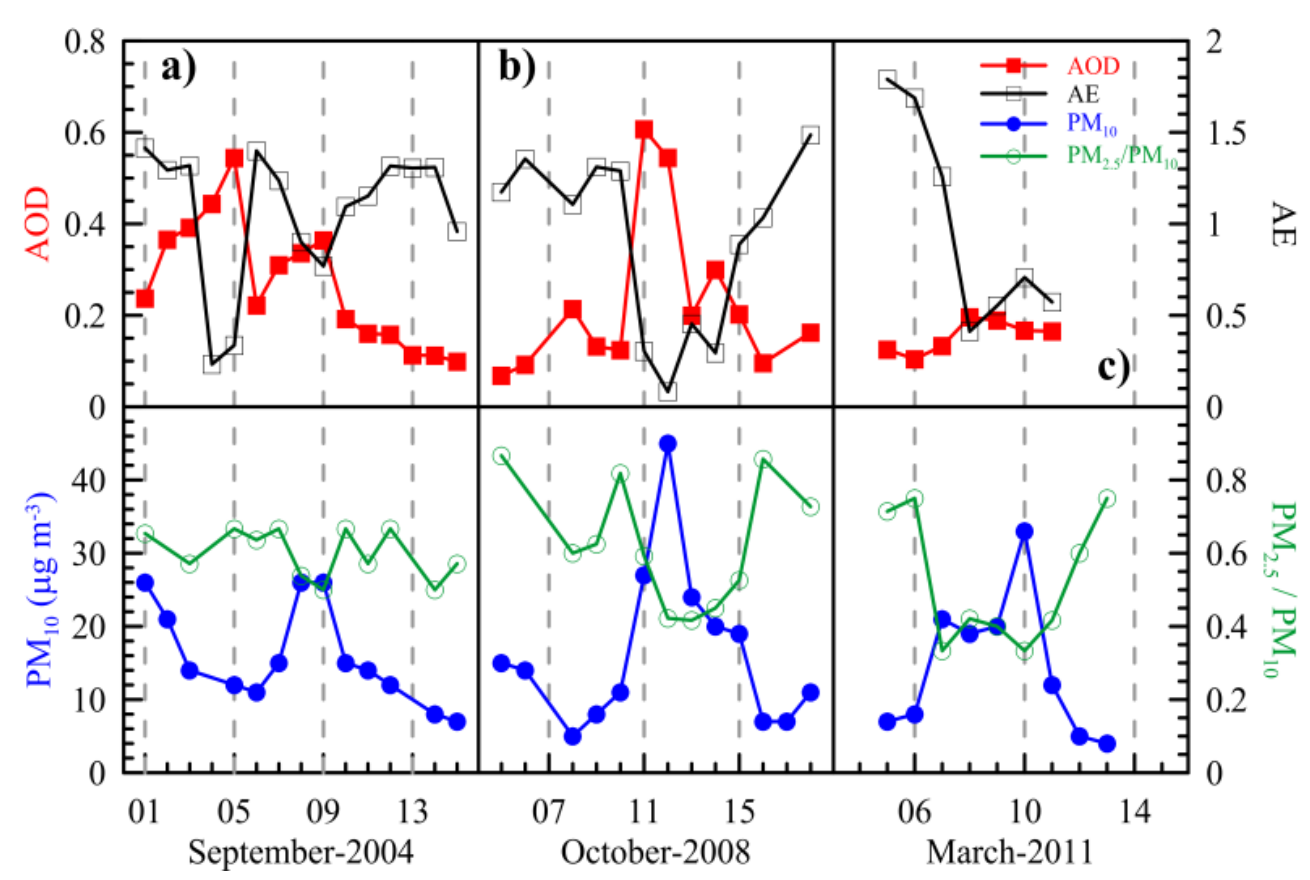

Figure 4. Time series of AOD (solid squares), AE (open squares), $\mathrm{PM}_{10}$ (solid circles), and $\mathrm{PM}_{2.5} / \mathrm{PM}_{10}$ (open circles) during three particular DD events quoted in the text. 
Overall, most of the strong and extreme DD intrusions of AOD (>0.3) also present $\mathrm{PM}_{10}$ values $>25$ $\mu \mathrm{g} \mathrm{m}^{-3}$. However, the discrepancy between surface and columnar impact of DD aerosols frequently occurs due to delays in the deposition phenomena. There are $\mathrm{PM}_{10}$ values below $15 \mu \mathrm{g} \mathrm{m}^{-3}$ and $\mathrm{PM}_{2.5} / \mathrm{PM}_{10}>0.5$ with a high AOD. For instance, on September 5th, $2004\left(\mathrm{PM}_{10}=12 \mu \mathrm{g} \mathrm{m}^{-3}, \mathrm{AOD}=\right.$ 0.54, $\mathrm{AE}=0.33$, and $\mathrm{PM}_{2.5} / \mathrm{PM}_{10}=0.67$, see Figure $\left.4 \mathrm{a}\right)$ is enclosed in a 10 -day event $\left(1^{\text {st }}-10^{\text {th }}\right.$ September, 2004) which represents a DD outbreak with more impact on high atmospheric levels than at the surface. This DD event is also reported in south-western Spain by Prats et al. (2008) in the first fortnight of September-2004. The possible delay in deposition to the ground, considering the $24 \mathrm{~h}$ filter sampling in the surface concentration, could also produce large $\mathrm{PM}_{10}$ and low $\mathrm{PM}_{2.5} / \mathrm{PM}_{10}$ values with simultaneous weak columnar loads $(\mathrm{AOD}<0.3)$ when the event is starting/finishing.

For the MD subset, the intensity of columnar events is in general low to moderate, with AOD values $<0.4$, the majority of surface concentrations under $25 \mu \mathrm{g} \mathrm{m}^{-3}$ and $\mathrm{PM}_{2.5} / \mathrm{PM}_{10}$ ranging from 0.5 to 0.7. Overall, $\mathrm{MD}$ event days show lower $\mathrm{PM}_{10}$ and higher $\mathrm{PM}_{2.5} / \mathrm{PM}_{10}$ values than $\mathrm{D}$ type due to the presence of aerosol mixtures. In particular, there is larger frequency of biomass burning or anthropogenic aerosol events during summer (e.g., Mateos et al., 2015). Large variability of the $\mathrm{PM}_{10}$ occurs for the MD type and AOD ranges between 0.2 and 0.4. Overall, low AOD $(<0.2)$ implies $\mathrm{PM}_{10}<$ $20 \mu \mathrm{g} \mathrm{m}^{-3}$ with intermediate values of the $\mathrm{PM}_{2.5} / \mathrm{PM}_{10}$ ratio. However, large $\mathrm{PM}_{10}$ and low $\mathrm{PM}_{2.5} / \mathrm{PM}_{10}$ values can also occur for this AOD range. For instance, a 3-day event from 8th to 10th March, 2011 (see Figure 4c) represents a case with more impact at low atmospheric layers than in the column (e.g., $\mathrm{PM}_{10}$ $=33 \mu \mathrm{g} \mathrm{m}^{-3}, \mathrm{AOD}=0.16, \mathrm{AE}=0.7$, and $\mathrm{PM}_{2.5} / \mathrm{PM}_{10}=0.33$ on March 3rd, 2011). The 4-day event shows low AE values and AOD about 0.2 with surface concentrations ranging between 20 and $30 \mu \mathrm{g} \mathrm{m}^{-3}$ and $\mathrm{PM}_{2.5} / \mathrm{PM}_{10}$ about 0.4 .

\subsubsection{Relationships of columnar and surface quantities: $P M_{10}-A O D$ and $P M$ ratio-AE}

One important task carried out in aerosol studies in the last years has been the development of a method for monitoring surface aerosol levels (generally accomplished by air quality networks) by means of remote sensing data, such as the AOD data provided by satellite sensors (e.g., Liu et al., 2004; Kacenelenbogen et al., 2006; Rohen et al., 2011). A theoretical background supports this analysis between $\mathrm{AOD}$ and $\mathrm{PM}_{10}$ quantities (for further details see Bennouna et al., 2016). In the present study, the $\mathrm{AOD}-\mathrm{PM}_{10}$ and $\mathrm{AE}-\mathrm{PM}_{2.5} / \mathrm{PM}_{10}$ relationships are reported in Figure $\mathrm{S} 1$ only for mineral dust aerosols (the general comparison for the entire long-term database was presented by Bennouna et al., 2016). Overall the correlation or Pearson's coefficient $(\mathrm{R})$ is around 0.6 for $\mathrm{PM}_{10}$ vs AOD relationship, being lower ( $\mathrm{R} \sim 0.5)$ for $\mathrm{PM}_{2.5} / \mathrm{PM}_{10}$ vs AE. During DD intrusions the change of $\mathrm{PM}_{10}$ is larger than that shown by AOD (see linear fits in Figure S1). This fact can also be proved with the range of surface 
338

339

340

341

342

343

344

345

346

347

348

349

350

351

352

353

354

355

356

357

358

359

360

361

362

363

364

365

366

367

368

concentration values achieving a maximum of $\sim 200 \mu \mathrm{g} \mathrm{m}^{-3}$, meanwhile AOD does not reach 1.0. If the total mean values in the 2003-2014 period are used as reference $\left(\mathrm{PM}_{10}=10.3 \mu \mathrm{gm}^{-3}\right.$ and $\left.\mathrm{AOD}=0.13\right)$, the mentioned maxima correspond to changes around 20 and 8 times the mean values of $\mathrm{PM}_{10}$ and $\mathrm{AOD}$, respectively. Therefore, although the surface-columnar relationship presents limitations, there are still similarities that point out the usefulness of the joint interpretation of these two quantities during high turbidity events such as DD outbreaks.

\subsection{Annual cycle of AOD, $\mathrm{PM}_{10}, \mathrm{AE}$, and $\mathrm{PM}_{2.5} / \mathrm{PM}_{10}$ during $\mathrm{DD}$ events}

The annual cycles for DD event days obtained for AOD, $\mathrm{PM}_{10}, \mathrm{AE}$, and $\mathrm{PM}_{2.5} / \mathrm{PM}_{10}$ are shown in Figure 5. Regarding AOD, Figure 5a illustrates the intensity of the dusty days ( + MD curve). Maximum values about 0.32 appear in March and the summer months of July and August, local minimum in May and absolute minimum during the winter months ( 0.15 in January). The three annual cycles (D, MD, and D+MD) exhibit very similar AOD values in February, April, June and August. Overall, DD intensity is governed by D type but certain differences are noticeable. The maximum in March is governed by D type (reaching values up to 0.36) because MD event days have stable AOD from February to April. The decrease on the DD outbreak intensity in May is observed in both subsets, being more intense for the MD type. The slight AOD decrease in June in the D curve is counteracted by the large increase in the MD type. In July, the D type presents a more marked maximum with a notable fall in August, again, counteracted by the load increase during MD events. The behavior in September and October is ruled by MD type while D is the only event type encountered in November and December. To our knowledge, this study presents the first evaluation of the DD intensity monthly cycle for AOD in the western Mediterranean area. The seasonal means of AOD intensity during DD outbreaks over 4-year period (2003-2006) in Palencia site are studied by Basart et al., (2009) obtaining values in the interval $0.23-0.33$ (taking the wavelength of $670 \mathrm{~nm}$ ). This range is proven here to be still acceptable for a longer period (2003-2014) with values (at $440 \mathrm{~nm}$ ): 0.22 (DJF), 0.28 (MAM), 0.30 (JJA), and 0.24 (SON). With respect to the $\mathrm{AE}$, the variation of seasonal means in this study is almost negligible between 0.91 (MAM) and 0.96 (DJF and JJA) with the D type exhibiting seasonal values around 0.61. These figures are higher than those reported by Basart et al., (2009) around 0.45. This discrepancy can be attributed to the different AE criteria used to identify dusty days, established in 0.7 (Basart et al., 2009) or 1.0 (Cachorro et al., 2016). 
Some of the main characteristics shown for AOD are similar in the $\mathrm{PM}_{10}$ annual cycle for D+MD curve (see Figure 5b): maximum in March $\left(34 \mu \mathrm{g} \mathrm{m}^{-3}\right)$ and summer months (being in this case more prominent the month of August), local minima in April and May and absolute minimum during winter $372\left(16-18 \mu \mathrm{g} \mathrm{m}^{-3}\right)$. The D+MD seasonality is only governed by the $\mathrm{D}$ type, reaching its absolute maximum 373 in August with almost $40 \mu \mathrm{g} \mathrm{m}^{-3}$. The MD type shows a more stable pattern throughout the year, without marked changes. We have compared the magnitude of the $\mathrm{PM}_{10}$ seasonal cycle with that obtained in other regions of the Iberian Peninsula by Pey et al. (2013). These authors have reported the seasonal cycle intensity for the NE and SE sectors, which is quantitatively larger than our results for the northcentral area.

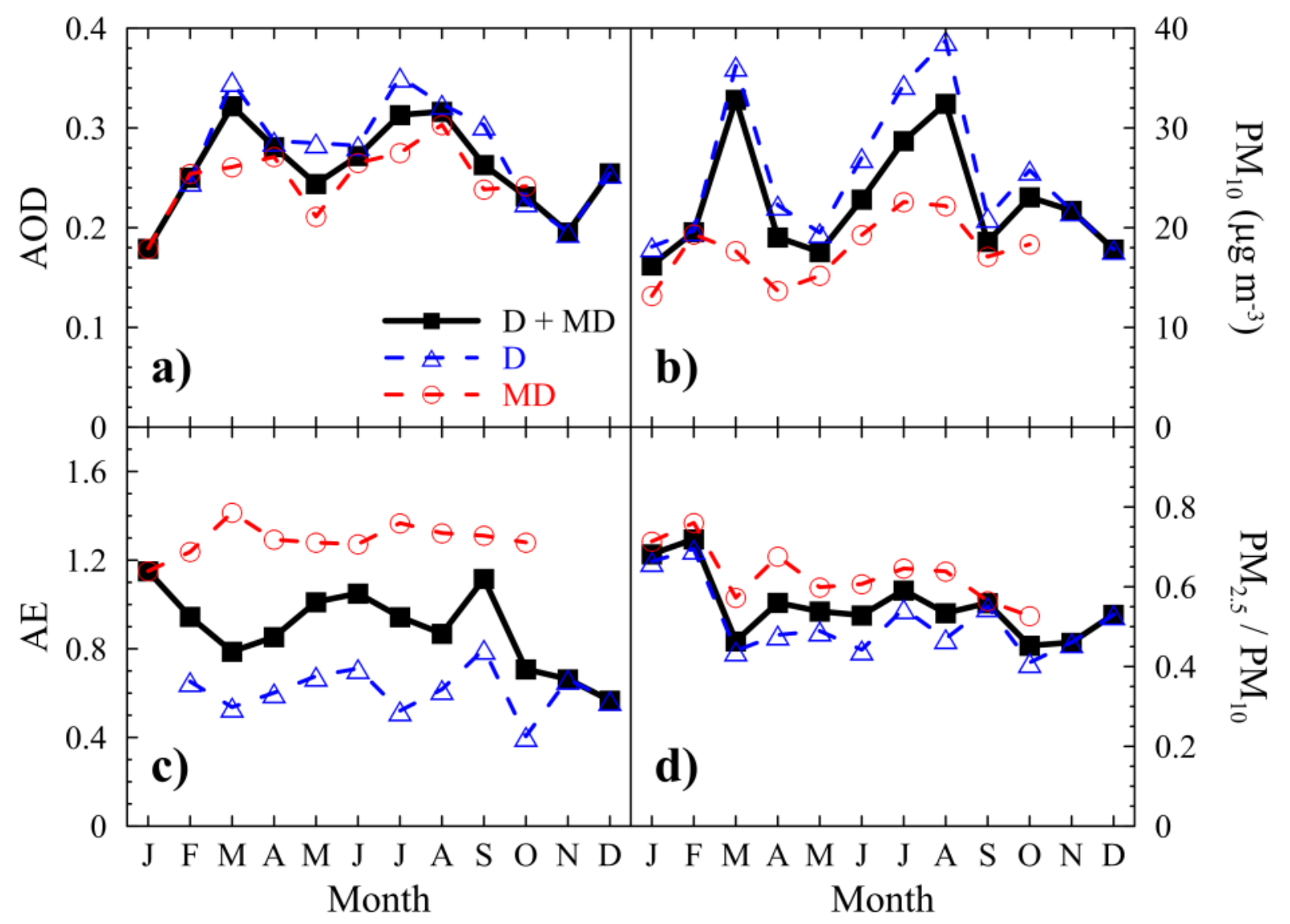

Figure 5. Annual cycles of $\mathrm{AOD}(\mathrm{a}), \mathrm{PM}_{10}$ (b, in $\mu \mathrm{g} \mathrm{m} \mathrm{m}^{-3}$ ), $\mathrm{AE}$ (c) and $\mathrm{PM}_{2.5} / \mathrm{PM}_{10}$ ratio (d) for the DD 382 inventory (squares) and the two subsets or categories of desert dust aerosols, D (triangles) and MD 383 (circles). 
The value of $\mathrm{AE}$ parameter, linked to particle size predominance (see Figure 5c), corroborates the well-known behavior mentioned above for DD intrusions by decreasing and increasing in an opposite way than AOD. Thus, the AOD maximum of March becomes a minimum of AE (about 0.8) and the same occurs during summer months. For D subset, the largest coarse particle predominance observed in October (annual minimum of $\mathrm{AE}, \sim 0.45$ ) is not linked to the most intense loads. However, the low $\mathrm{AE}$ observed in March and July, occur with the strongest events. The MD type follows an even distribution throughout the year.

Finally, the $\mathrm{PM}_{2.5} / \mathrm{PM}_{10}$ ratio (see Figure 5d) presents a strong minimum (larger concentration of coarse mode) in March of $\sim 0.5$ and a weak variability in the rest of the year. A particular difference with respect to $\mathrm{AE}$ is observed in July: the ratio values increase from June and $\mathrm{AE}$ decreases indicating a different weight of fine/coarse particles at the surface and the entire column. The minimum of D type in the $\mathrm{AE}$ in October is also observed in the $\mathrm{PM}_{2.5} / \mathrm{PM}_{10}$ ratio but this is not as pronounced as in the $\mathrm{AE}$ (local minimum compared to September and November). There is a small difference between $\mathrm{PM}_{2.5} / \mathrm{PM}_{10}$ values for the $\mathrm{D}$ and $\mathrm{MD}$ types. In addition, for most of the year their behaviour is similar, being only remarkable the difference in August and September.

\subsection{Characterization of columnar microphysical properties during DD events}

\subsubsection{Columnar volume particle size distribution}

$\mathrm{AE}$ and $\mathrm{PM}$ ratio are simple derived parameters used to represent the particle size predominance. The columnar microphysical properties obtained by inversion methods (Dubovik et al., 2000; 2006; Torres et al., 2014) are more explicit quantities, such as the columnar volume particle size distribution and its derived parameters: volume concentration, effective radius for total, fine and coarse modes, fine mode volume fraction, etc. Therefore, these columnar microphysical properties have been investigated during DD events in the study area. As a first step, VPSD during these outbreaks is compared to the overall mean of available AERONET inversion data, in Figure 6a. The VPSD for all data exhibits a clear bimodality, the fine mode peaks at $0.15 \mu \mathrm{m}$ and the coarse mode at $2.24 \mu \mathrm{m}$ (but with a large flat shape between 1 and $3.5 \mu \mathrm{m}$ ), being the concentrations about $0.011 \mu \mathrm{m}^{3} / \mu \mathrm{m}^{2}$. This feature is already reported by, e.g., Prats et al., (2011) in southern Spain but only during the cold season (November through February), since in the summer months the southern area has a clear coarse particle predominance. This fact highlights the difference between northern and southern areas of the Iberian Peninsula with respect to the aerosol properties and seasonality. 


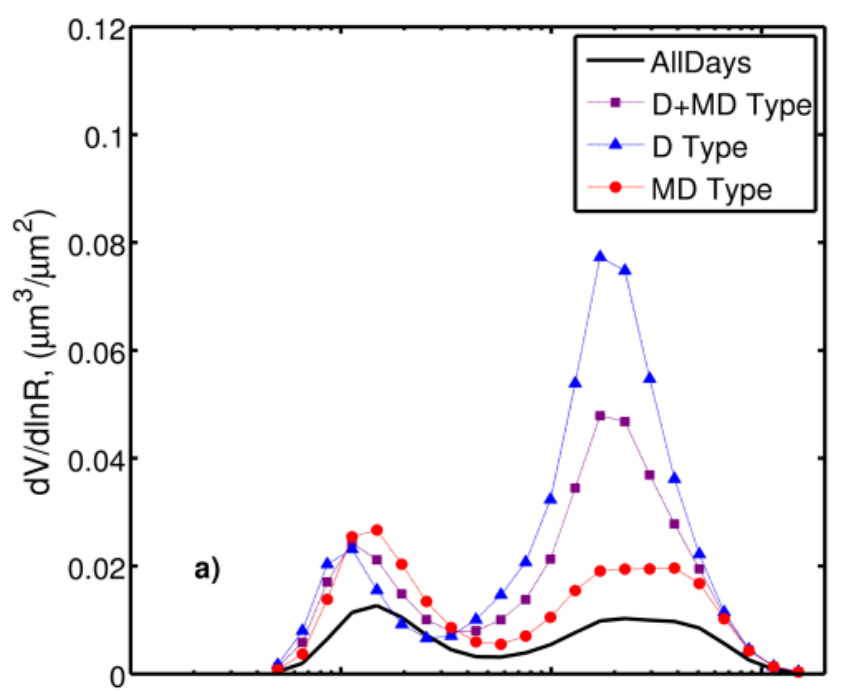

416

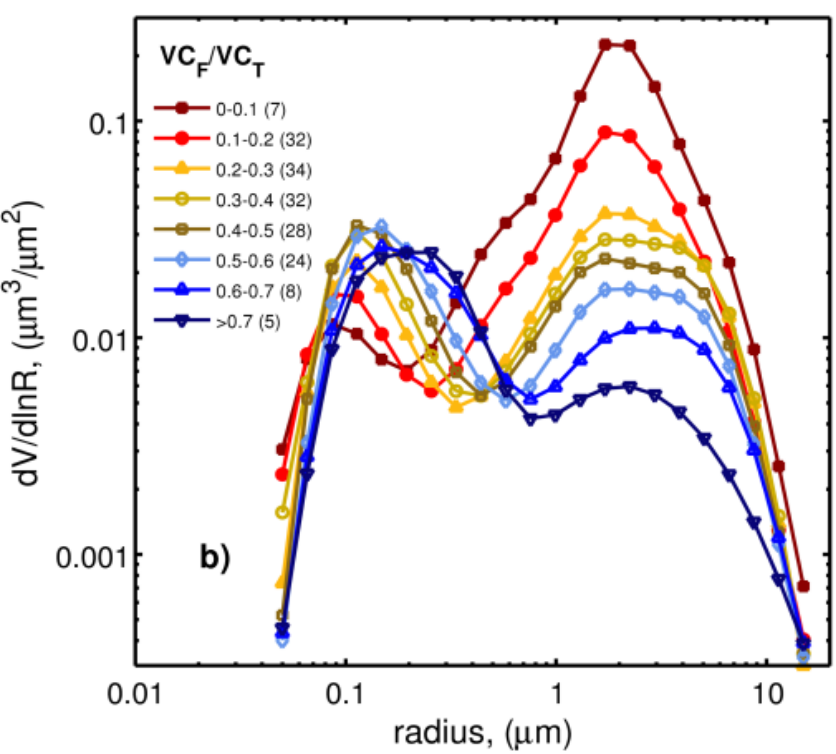

Figure 6. Aerosol volume size distribution at Palencia AERONET site in 2003-2014: a) for All days (solid black line), all dusty days (D+MD, lilac squares), and D (blue triangles) and MD (red circles) event days; b) for the entire $\mathrm{V}_{\mathrm{F}} / \mathrm{V}_{\mathrm{T}}$ range.

However, these characteristics are strongly modified during DD events. For the total number of DD event days ( $\mathrm{D}+\mathrm{MD}$ curve), the increase of the coarse mode concentration is evident and presents a slimmer shape compared to the former. Besides, a more prominent maximum appears about $2 \mu \mathrm{m}$ radius, which is in the size range (1-3.5 $\mu \mathrm{m})$ reported by Ryder et al. (2013) in the Central Sahara and is similar to the values reported at other sites affected by African desert dust (e.g., Cuesta et al., 2008; Guirado et al., 2014). The fine mode concentration does not suffer any reduction during these events, as 
it was also reported by previous studies in other Mediterranean sites (e.g. Gkikas et al., 2013). In this mode, the center of the peak is also shifted to smaller radii $(0.11 \mu \mathrm{m})$.

Concerning the D type, the mean VPSD peaks at $1.7 \mu \mathrm{m}\left(0.08 \mu \mathrm{m}^{3} / \mu \mathrm{m}^{2}\right)$. It is noticeable that for both fine and coarse mode, the maxima are shifted to smaller radii with respect to the overall mean (black line in Figure 6a). In presence of mixtures with dust (MD curve) the fine mode concentration is on average higher than the coarse mode.The fine mode peaks at $0.15 \mu \mathrm{m}$, slightly shifted to larger radii when compared to the D curve but with a similar concentration. The features presented here about VPSD for DD are in line with previous studies in the Mediterranean Basin for particular or strong DD episodes (e.g., Tafuro et al., 2006; Cachorro et al., 2008; Prats et al., 2008; Valenzuela et al., 2012; among others).

Eck et al. (2010) obtained a notable dependence of VPSD curves on the fine mode volume fraction, presenting large fine mode concentrations under certain mixture conditions of desert dust with biomass burning at Ilorin site in Nigeria. Similar results were reported by Toledano et al. (2011) for Cape Verde islands, when DD episodes occuring at different heights and mixed with biomass burning aerosols were analyzed. Figure $6 \mathrm{~b}$ shows the VPSD dependence on $\mathrm{VC}_{\mathrm{F}} / \mathrm{VC}_{\mathrm{T}}$ (the ratio of volume concentration for the fine mode, $\mathrm{VC}_{\mathrm{F}}$, to the total one, $\mathrm{VC}_{\mathrm{T}}$ ). The VPSD curves for the strongest coarse concentrations (corresponding to $\mathrm{VC}_{\mathrm{F}} / \mathrm{VC}_{\mathrm{T}} \leq 0.2$ ) present the maximum concentration at about $2 \mu \mathrm{m}$ radii and the fine mode is almost negligible. Furthermore, a small concentration increase about $0.6 \mu \mathrm{m}$ is found, which could be analogous to the third mode reported by Eck et al. (2010) and Toledano et al. (2011) for dust observed nearby the Sahara desert. This third mode is an unusual characteristic in most worldwide aerosol sites. Hence, DD intrusions observed in our study area with $\mathrm{VC}_{\mathrm{F}} / \mathrm{VC}_{\mathrm{T}} \leq 0.2$ show the expected characteristics for Saharan mineral dust aerosols. The feature at $0.6 \mu \mathrm{m}$ dissapears in Figure $6 \mathrm{~b}$ for larger fine mode fractions; in contrast to the previous studies nearby Sahara, which present this extramode until intermediate fine mode fractions. In the $0.2<\mathrm{VC}_{\mathrm{F}} / \mathrm{VC}_{\mathrm{T}}<0.5$ range, bimodality is evident with similar concentration in the fine and coarse modes. With respect to the coarse mode, the maximum concentration is shifted to larger radii between 2 and $4 \mu \mathrm{m}$ for increasing fine mode fraction, while the fine mode peaks around $0.1 \mu \mathrm{m}$. When the fine mode predominates $\left(\mathrm{VC}_{\mathrm{F}} / \mathrm{VC}_{\mathrm{T}}>0.5\right)$, its radius for the maximum concentration is shifted to larger values, between 0.15 and $0.30 \mu \mathrm{m}$.

To understand the role played by mixtures during African dust episodes in central Iberian Peninsula, Salvador et al. (2013) reported the mean source contributions to $\mathrm{PM}_{10}$ values in the Madrid region for short field campaigns. Their results highlight that mineral contribution can achieve the $66 \%$ of the total bulk of $\mathrm{PM}_{10}$ during dusty days for a rural environment, while the remaining 'non-negigible' percentage is attributed to road traffic, secondary inorganic aerosol, sea salt, among others. Furthermore, no less 
462 than $25 \%$ of other sources are even present when the daily limit value of $\mathrm{PM}_{10}=50 \mu \mathrm{g} \mathrm{m}^{-3}$ is overcome 463 during intense DD intrusions.

3.3.2. Relationships between the size and shape parameters: AE, fine mode volume fraction, sphericity, and $P M_{2.5} / P M_{10}$

Different parameters representing the aerosol size are directly derived from the VPSD, such as the effective radius or the fine mode volumen fraction $\left(\mathrm{VC}_{\mathrm{F}} / \mathrm{VC}_{\mathrm{T}}\right)$. This latter quantity may be considered analogous to the surface PM ratio $\left(\mathrm{PM}_{2.5} / \mathrm{PM}_{10}\right)$. Besides, the AE obtained from the AOD spectral dependence is also related to the prevailing aerosol size (Eck et al., 2008). A relevant quantity provided by the AERONET inversion algorithm (Dubovik et al., 2006) is the sphericity (portion of spherical particles), ranging from 0 to 1 and thus indicating the spherical (values near 1) or non-spherical (values near 0) shape of the aerosol particles. The relationships between these four quantities related to the aerosol size and shape in different ways are studied in this subsection, with focus on their general features as part of the aerosol characterization of mineral dust and its mixtures over our study area.

Figure $7 \mathrm{a}$ shows how the $\mathrm{VC}_{\mathrm{F}} / \mathrm{VC}_{\mathrm{T}}$ ratio is related to the $\mathrm{Angström}$ exponent, which is a more simple parameter to obtain. Overall, the correlation between $\mathrm{VC}_{\mathrm{F}} / \mathrm{VC}_{\mathrm{T}}$ and $\mathrm{AE}$ is in general poor, as obtained by previous studies such as Prats et al., (2011) for "El Arenosillo" site in the south-western Iberian Peninsula; Rodríguez et al., (2012) and Toledano et al., (2012) in Sub-Arctic areas. However, the correlation is higher when only D-type intrusions are analyzed, with a correlation coefficient $\sim 0.8$ showing an almost linear dependence for $\mathrm{AE}$ values up to 1.0. The correlation is much lower for the MD type ( $\mathrm{R} 0.4$ ) without any marked dependence. In order to extend the columnar analysis to the surface, the $\mathrm{VC}_{\mathrm{F}} / \mathrm{VC}_{\mathrm{T}}$ vs $\mathrm{PM}_{2.5} / \mathrm{PM}_{10}$ scatterplot is shown in Figure $7 \mathrm{~b}$. High dispersion leading to a weak correlation is observed. The highest correlation is obtained for $\mathrm{D}$ event days with $\mathrm{R} \sim 0.6$ ( $\sim 0.3$ for MD type). Overall, an increasing trend of $\mathrm{PM}_{2.5} / \mathrm{PM}_{10}$ from 0.2 to 0.9 is observed in the entire range of $\mathrm{VC}_{\mathrm{F}} / \mathrm{VC}_{\mathrm{T}}$. This novel result must be highlighted because of the different techniques used to derive PM ratio values and columnar inversion products. The lower sampling frequency of Sun photometer inversion products $\left(\mathrm{VC}_{\mathrm{T}}, \mathrm{VC}_{\mathrm{F}}\right.$ and Sphericity, see Table 1) have also caused a notable reduction in the number of availabe data, 182 in Figure 7a and 165 in Figure 7b, from the total of 304 with simultaneous $\mathrm{AOD}$ and $\mathrm{PM}_{10}$ data. Hence, this fact difficults the usage of these quantities in the DD detection process. 

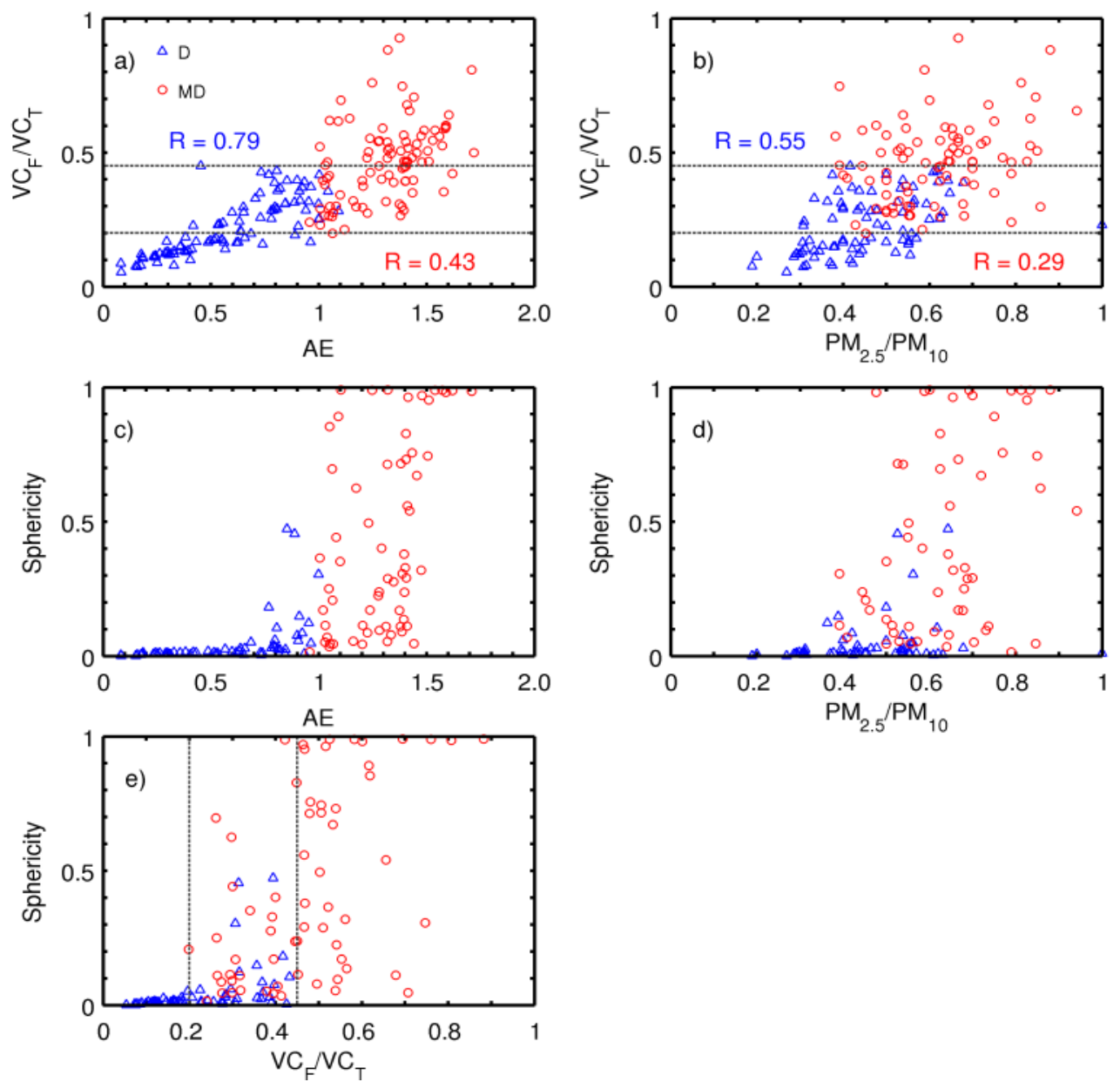

491 Figure 7. Scatterplots of: a) $\mathrm{VC}_{\mathrm{F}} / \mathrm{VC}_{\mathrm{T}}$ vs $\mathrm{AE}$, b) $\mathrm{VC}_{\mathrm{F}} / \mathrm{VC}_{\mathrm{T}}$ vs $\mathrm{PM}_{2.5} / \mathrm{PM}_{10}$, c) Sphericity vs $\mathrm{AE}$, d) 492 Sphericity vs $\mathrm{PM}_{2.5} / \mathrm{PM}_{10}$, and e) Sphericity vs $\mathrm{VC}_{\mathrm{F}} / \mathrm{VC}_{\mathrm{T}}$ for the $\mathrm{D}$ (blue triangles) and $\mathrm{MD}$ (red circles) 493 event days.

A general feature can be drawn from Figures 7a-b: three zones have been identified considering the type of DD intrusions falling in each one. First at all, those intrusions with a predominant coarse mode $\left(\mathrm{VC}_{\mathrm{F}} / \mathrm{VC}_{\mathrm{T}} \leq 0.2\right)$ are only of $\mathrm{D}$ type, with $\mathrm{AE}$ below 0.7 and $\mathrm{PM}_{2.5} / \mathrm{PM}_{10}$ between 0.2 and 0.6. This behavior is an indicator of strong coarse particle predominance in the atmospheric column meanwhile weak mixture conditions can occur at the surface. About a quarter of all the available points fall in this interval of $\mathrm{VC}_{\mathrm{F}} / \mathrm{VC}_{\mathrm{T}}$. In contrast, there is a zone where the fine mode predominates even in the presence of dust $\left(\mathrm{VC}_{\mathrm{F}} / \mathrm{VC}_{\mathrm{T}} \geq 0.45, \mathrm{AE}>1.2\right.$ and $\left.0.5<\mathrm{PM}_{2.5} / \mathrm{PM}_{10}<1.0\right)$ being all classified as $\mathrm{MD}$ type. The presence of mineral dust is always ensured by the analysis of the ancillary information described in Section 2.2. Furthermore, the intermediate zone $\left(0.2<\mathrm{VC}_{\mathrm{F}} / \mathrm{VC}_{\mathrm{T}}<0.45\right)$ presents both $\mathrm{D}$ and $\mathrm{MD}$ types with a wide range of $\mathrm{AE}(0.6-1.8)$ and $\mathrm{PM}$ ratio (0.3-0.8) values, which corroborates the relevance of 
analyzing aerosol mixtures including mineral dust over our site. About $75 \%$ of the total DD event days with columnar inversion products present mixtures in greater or lesser extent. These three established zones of $\mathrm{VC}_{\mathrm{F}} / \mathrm{VC}_{\mathrm{T}}$ can be considered a main feature in the study of other aerosol properties during $\mathrm{DD}$ outbreaks.

The non-spherical shape of mineral dust aerosols has been extensively demonstrated (e.g., Dubovik et al., 2006; Eck et al., 2005; Prats et al., 2008; Bedareva et al., 2014; Taylor et al., 2015), hence this is a key parameter in the aerosol characterization studies. The AERONET retrievals of sphericity fraction (e.g, Dubovik et al., 2006) are used in this section. Figures 7c-e show the sphericity vs AE, $\mathrm{PM}_{2.5} / \mathrm{PM}_{10}$, and $\mathrm{VC}_{\mathrm{F}} / \mathrm{VC}_{\mathrm{T}}$ scatterplots, respectively. Overall, the mean sphericity fraction during DD episodes is 0.25 , being as low as 0.05 for D type and about 0.4 for MD type. As expected, most of aerosols present non-spherical shapes (sphericity fraction values below 0.20 in the $64 \%$ of the cases), but a nonnegligible part (16\%) nearly displays a predominant spherical shape (sphericity fraction beyond 0.70 ). For the D type, most of the sphericity fractions are below 0.20 pointing out the predominance of nonspherical particles, whereas sphericity in the MD type spans in the entire 0-1 interval indicating mixtures of spherical and non-spherical particles in different proportions.

Figure 7c clearly shows two well defined areas below and above AE=1, demonstrating that aerosols with AE values below 1 are very predominantly DD aerosol because of the very low sphericity fraction, whereas above $\mathrm{AE}=1$ we can find a mixture of particle shapes with a high variability in the sphericity fractions. On the other hand, as can be seen in Figure 7d, PM ratio and sphericity do not follow any correspondence, thus demonstrating the less ability of PM ratio for DD detection.

In terms of the $\mathrm{VC}_{\mathrm{F}} / \mathrm{VC}_{\mathrm{T}}$ ranges established above, the mean sphericity fraction is about 0.01 for $\mathrm{VC}_{\mathrm{F}} / \mathrm{VC}_{\mathrm{T}} \leq 0.2$. Hence, those cases showing $\mathrm{AE}$ values below 0.7 and $\mathrm{PM}_{2.5} / \mathrm{PM}_{10}$ between 0.2 and 0.6 present non-sphericity, as it is typical in Saharan surroundings (e.g., Dubovik et al., 2006). For the interval $0.2<\mathrm{VC}_{\mathrm{F}} / \mathrm{VC}_{\mathrm{T}}<0.45$ ), the mean portion of spherical particles increases up to 0.17 . These two fractions are in line with previous studies analyzing areas with notable weight of dust particles (e.g., Taylor et al., 2015). The mean sphericity values in these two first intervals of $\mathrm{VC}_{\mathrm{F}} / \mathrm{VC}_{\mathrm{T}}$ (where coarse mode predominates) highlight that the choice of the selected threshold of $\mathrm{AE}=1$ in order to distinguish between $\mathrm{D}$ and MD dusty days in our study area is reliable and correct, since this quantity hardly reaches values of 0.17 . Finally, those cases with $\mathrm{VC}_{\mathrm{F}} / \mathrm{VC}_{\mathrm{T}} \geq 0.45$ show a mean sphericity fraction of 0.56 , thus indicating a minor role of mineral dust particles.

All the results presented in this subsection, with a wide range of $\mathrm{AE}, \mathrm{VC}_{\mathrm{F}} / \mathrm{VC}_{\mathrm{T}}, \mathrm{PM}$ ratio, and spherictiy fraction, point out a mixture of aerosols, but the purer DD intrusions are reliably detected too. 
538 The large number of mixture cases is due to the low-moderate DD events registered. Besides, these 539 results again highlight that the detection of strong $\mathrm{DD}$ events could be affordable using $\mathrm{AE}, \mathrm{VC}_{\mathrm{F}} / \mathrm{VC}_{\mathrm{T}}$ or

540 sphericity, but bearing in mind that the amount of available columnar inversion data is much less than $\mathrm{AOD}$ and $\mathrm{AE}$ observations. Hence, the most suitable quantity to carry out this task is the Ångström exponent, which can present DD fingerprints even in low and moderate episodes.

\subsubsection{Effective radius and its relation with other particle size parameters}

Effective radius is the most important parameter representing the size of the VPSD, thus its relation with the other quantities related to the particle size is of general interest for atmospheric aerosol community. Figure 8 displays the Effective Radius $(\mathrm{ER})$ for the total $\left(\mathrm{ER}_{\mathrm{T}}\right)$, fine $\left(\mathrm{ER}_{\mathrm{F}}\right)$, and coarse $\left(\mathrm{ER}_{\mathrm{C}}\right)$ modes vs $\mathrm{AE}, \mathrm{VC}_{\mathrm{F}} / \mathrm{VC}_{\mathrm{T}}$, and $\mathrm{PM}_{2.5} / \mathrm{PM}_{10}$ size parameters. Figure $8 \mathrm{c}$ is the first attempt, to our knowledge, of establishing a relationship between columnar microphysical and surface aerosol size properties. Both $\mathrm{ER}_{\mathrm{F}}$ and $\mathrm{ER}_{\mathrm{C}}$ span in the following tight intervals: $(0.1,0.22 \mu \mathrm{m})$ and $(1.3,3 \mu \mathrm{m})$, respectively. Therefore, as it can be seen in Figure $8 \mathrm{a}$ they are practically independent of $\mathrm{AE}, \mathrm{VC}_{\mathrm{F}} / \mathrm{VC}_{\mathrm{T}}$ or $\mathrm{PM}_{2.5} / \mathrm{PM}_{10}$. On the contrary, $\mathrm{ER}_{\mathrm{T}}$ shows a wider range between 0.15 and $1.2 \mu \mathrm{m}$, and certain correlation with $\mathrm{AE}, \mathrm{VC}_{\mathrm{F}} / \mathrm{VC}_{\mathrm{T}}$ or $\mathrm{PM}_{2.5} / \mathrm{PM}_{10}$ is to be expected in spite of the different size information contained in each quantity. The correlation coefficients for our DD database are -0.8 for $\mathrm{ER}_{\mathrm{T}} \mathrm{Vs} \mathrm{AE},-0.9$ for $\mathrm{ER}_{\mathrm{T}}$ vs $\mathrm{VC}_{\mathrm{F}} / \mathrm{VC}_{\mathrm{T}}$, and -0.6 for $\mathrm{ER}_{\mathrm{T}}$ vs $\mathrm{PM}_{2.5} / \mathrm{PM}_{10}$. I.e., the larger the $\mathrm{AE}$ or $\mathrm{VC}_{\mathrm{F}} / \mathrm{VC}_{\mathrm{T}}$ or $\mathrm{PM}_{2.5} / \mathrm{PM}_{10}$, the smaller the total effective radius.

The largest particles during DD outbreaks are placed in the $\mathrm{ER}_{\mathrm{T}}$ range of $0.5-1.2 \mu \mathrm{m}$ and they correspond to $\mathrm{AE}$ values below $0.5, \mathrm{VC}_{\mathrm{F}} / \mathrm{VC}_{\mathrm{T}} \leq 0.2$, and $\mathrm{PM}$ ratio up to $\sim 0.5$, being only $\mathrm{D}$ type intrusions. However, there are similar $\mathrm{PM}_{2.5} / \mathrm{PM}_{10}$ values occurring for smaller particles $\left(\mathrm{ER}_{\mathrm{T}}\right.$ of $0.2-$ $0.5 \mu \mathrm{m}$ for $\mathrm{D}$ and $\mathrm{MD}$ types), which does not happen in the $\mathrm{AE}$ and $\mathrm{VC}_{\mathrm{F}} / \mathrm{VC}_{\mathrm{T}}$ intervals. Overall, the mean $\mathrm{ER}_{\mathrm{T}}$ during all events is $0.40 \mu \mathrm{m}$, which increases up to $0.50 \mu \mathrm{m}$ for $\mathrm{D}$ type cases and decreases until $0.31 \mu \mathrm{m}$ for MD type cases.

The highest correlation between $\mathrm{AE}$ and $\mathrm{ER}_{\mathrm{T}}$ is found for the $\mathrm{D}$ type with a correlation coefficient of -0.78, which is also noticeable $(\mathrm{R}=-0.88)$ in the $\mathrm{ER}_{\mathrm{T}} \mathrm{vs} \mathrm{VC}_{\mathrm{F}} / \mathrm{VC}_{\mathrm{T}}$ scatterplot and slightly lower in the $\mathrm{ER}_{\mathrm{T}}$ vs $\mathrm{PM}_{2.5} / \mathrm{PM}_{10}$ scatterplot $(\mathrm{R}=-0.6)$. The scatterplots present different behaviors: $\mathrm{ER}_{\mathrm{T}} \mathrm{vs} \mathrm{AE}$ and $\mathrm{PM}_{2.5} / \mathrm{PM}_{10}$ exhibit linear relationship (Figures $8 \mathrm{a}$ and $8 \mathrm{c}$ ) while power functions are used to fit $\mathrm{ER}_{\mathrm{T}} \mathrm{vs}$ $\mathrm{VC}_{\mathrm{F}} / \mathrm{VC}_{\mathrm{T}}$ (Figure $8 \mathrm{~b}$ ). Note that logarithmic scale is used for the y axis. With respect to MD event days, high correlation $(\mathrm{R} \sim 0.8)$ is observed in Figure $8 \mathrm{~b}$ in the $\mathrm{VC}_{\mathrm{F}} / \mathrm{VC}_{\mathrm{T}}$ analysis, whilst $\mathrm{AE}$ and $\mathrm{PM}_{2.5} / \mathrm{PM}_{10}$ are almost independent on $\mathrm{ER}_{\mathrm{T}}$ (with slope of linear fits close to 0 and $\mathrm{R}$ below 0.5 ). 

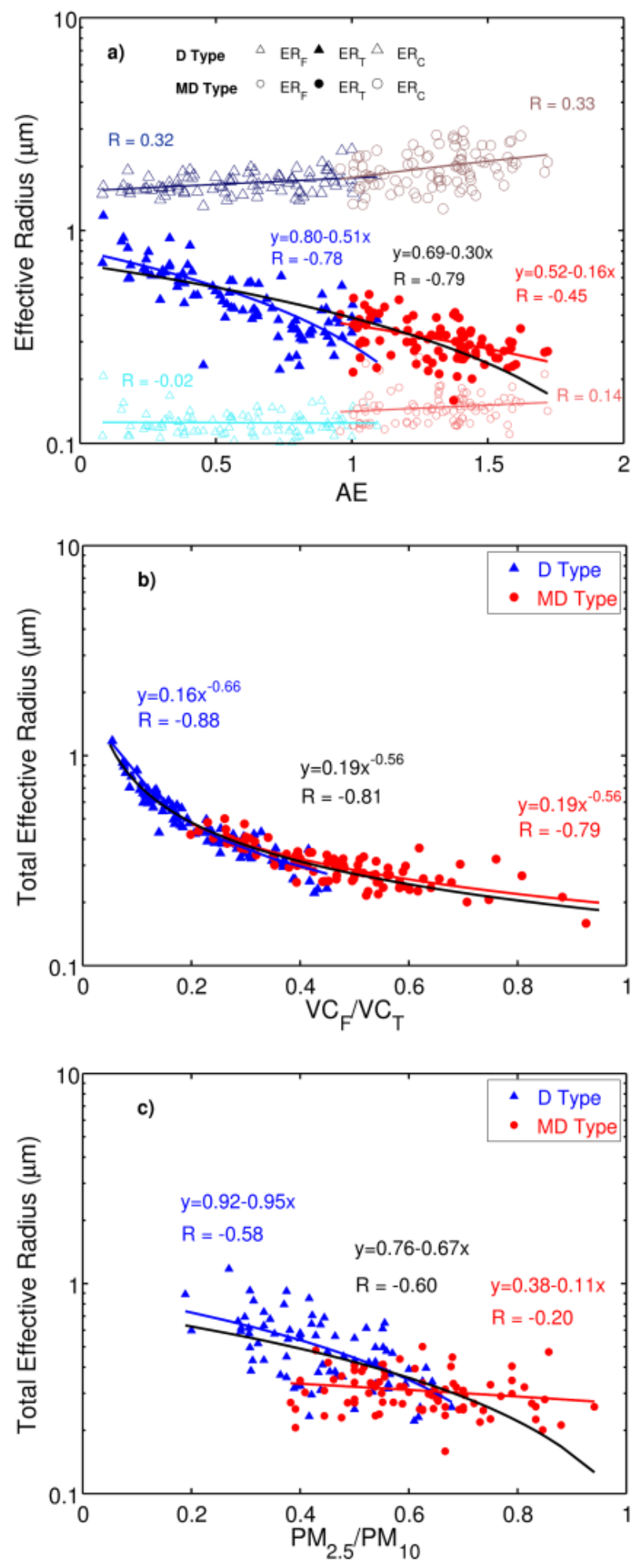

Figure 8. Scatterplots of: a) Effective Radius for total, coarse, and fine modes vs Ångström exponent for $\mathrm{D}$ (blue triangles) and $\mathrm{MD}$ (red circles) event days; b) idem for $\mathrm{VC}_{\mathrm{F}} / \mathrm{VC}_{\mathrm{T}}$; and c) idem for $\mathrm{PM}_{2.5} / \mathrm{PM}_{10}$. Solid lines are the fits of each analysis, being the black one the fit for the total DD database. 
00

The analysis of dusty days allows establishing a consistent relationship between the total effective radius and $\mathrm{AE}$ (Prats et al., 2008). The higher correlation for the $\mathrm{ER}_{\mathrm{T}} \mathrm{Vs} \mathrm{VC}_{\mathrm{F}} / \mathrm{VC}_{\mathrm{T}}$ study is related to the fact that the both variables are retrieved in the same inversion process (e.g., Gonzi et al., 2002; Prats et al., 2011; Rodríguez et al., 2012). Finally, Figure 8c shows certain correlation $(R=-0.58)$ between the total effective radius and PM ratio recorded at surface for the D type aerosol. All these features are in line with previous results discussed in Figures 6 and 7.

3.3.4. Columnar volume particle concentration and its relationship with AOD and surface mass concentration

Columnar aerosol load can also be expressed by means of the columnar volume (or mass) particle concentration derived from the VPSD, where we can separate the concentration of the fine and the coarse modes. Aerosol optical depth can be expressed as a function of the columnar volume (or mass) particle concentration (e.g., Fraser et al., 1984; Kokhanovsky, et al., 2009), defining the columnar volume efficiency factor $E_{\mathrm{V}}$. Empirical relationships between $\mathrm{AOD}$ and total volume particle concentration $\left(\mathrm{VC}_{\mathrm{T}}\right)$ were analyzed in previous studies (Prats et al., 2011; Toledano et al., 2012). These studies highlight that the relationship between these two columnar quantities represented by $\mathrm{E}_{\mathrm{V}}$ is ruled by the $\mathrm{VC}_{\mathrm{F}} / \mathrm{VC}_{\mathrm{T}}$ ratio. In order to empirically prove this kind of relationship for dusty days in northcentral Iberian Peninsula, Table 3 and Figure 9 illustrate the linear relationship between different columnar and surface quantities during DD events using the three intervals established in Figure 7. Figure 9 is depicted as an example of visualization of this kind of scatterplots for the AOD vs $\mathrm{VC}_{\mathrm{T}}$, $\mathrm{PM}_{10}$ vs $\mathrm{VC}_{\mathrm{T}}$, and $\mathrm{AOD}$ vs $\mathrm{PM}_{2.5}$ cases. Linear fits without intercept have been assumed in order to avoid the lack of physical meaning for no aerosol conditions. 

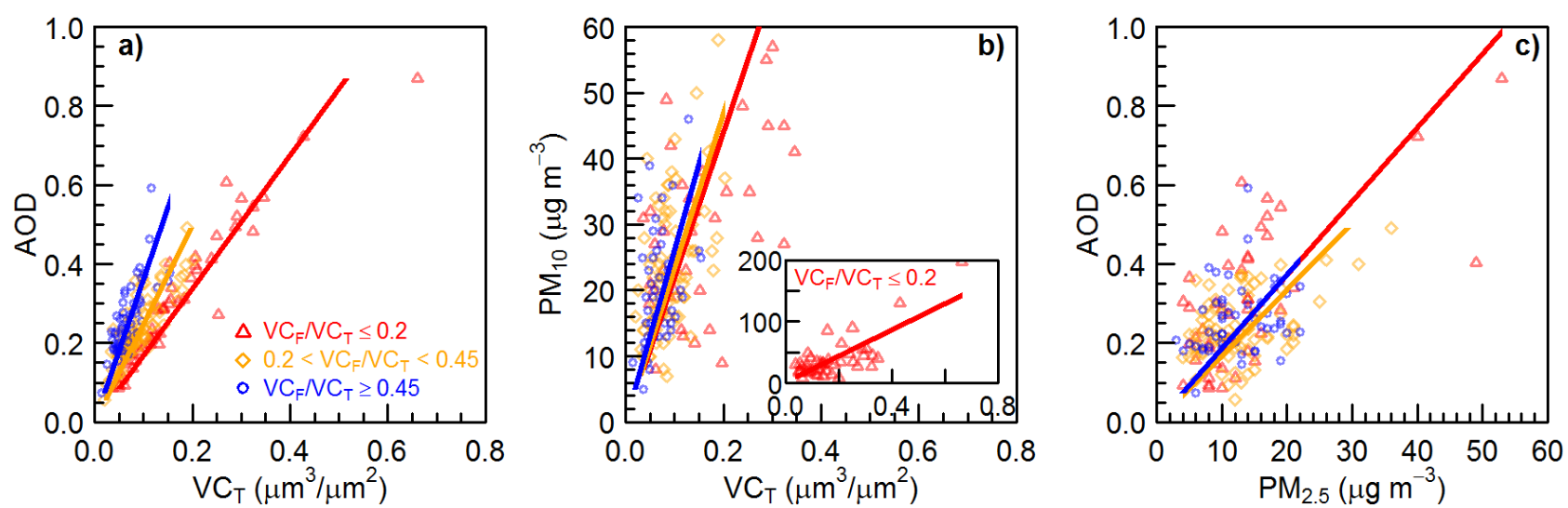

603 604 605 606 607 608 609 610 611 612 613 614 615 616 617 618 619 620 621 622 623 624 625 626

Figure 9. AOD vs $\mathrm{VC}_{\mathrm{T}}$ (a), $\mathrm{PM}_{10}$ vs $\mathrm{VC}_{\mathrm{T}}$ (b), and $\mathrm{AOD}$ vs $\mathrm{PM}_{2.5}$ (c) for three different intervals of $\mathrm{VC}_{\mathrm{F}} / \mathrm{VC}_{\mathrm{T}}$ during $\mathrm{DD}$ episodes. Linear fits are reported in Table 3.

For the coarse-mode-dominated cases $\left(\mathrm{VC}_{\mathrm{F}} / \mathrm{VC}_{\mathrm{T}} \leq 0.2\right)$, there is an excellent agreement between $\mathrm{VC}_{\mathrm{T}}$ and AOD (Figure 9a), with $\mathrm{R}$ values about 0.98 . The slopes of these fits are the columnar volume extinction efficiencies (e.g., Toledano et al., 2012) which present units of $\mu \mathrm{m}^{2} / \mu \mathrm{m}^{3}$. Hence, for a given $\mathrm{AOD}$, the larger the slope the smaller the $\mathrm{VC}_{\mathrm{T}}$. For strong $\mathrm{DD}$ outbreaks observed in south-western Spain in summer 2004, Prats et al. (2011) reported a mean efficiency value of $1.8 \mu \mathrm{m}^{2} / \mu \mathrm{m}^{3}$, with an extreme threshold of $1.4 \mu \mathrm{m}^{2} / \mu \mathrm{m}^{3}$ for coarse particles. Our columnar volume extinction efficiency for this category $\left(1.7 \mu \mathrm{m}^{2} / \mu \mathrm{m}^{3}\right)$ falls between these two values. As the fine mode gains weight, the slope becomes larger, up to a value of $3.7 \mu \mathrm{m}^{2} / \mu \mathrm{m}^{3}$ for $\mathrm{VC}_{\mathrm{F}} / \mathrm{VC}_{\mathrm{T}} \geq 0.45$. This figure in is line with previous results for fine particles in southern Spain (Prats et al., 2010) and Sub-Arctic areas (Toledano et al., 2012). The $\mathrm{VC}_{\mathrm{F}} / \mathrm{VC}_{\mathrm{T}}$ governs the columnar volume extinction efficiency, related to different aerosol types. Overall, the mean columnar volume extinction efficiency obtained during all dusty days is about $2.1 \pm 0.06 \mu \mathrm{m}^{2} / \mu \mathrm{m}^{3}$.

To correctly interpret the slope of $\mathrm{PM}_{10}$ vs $\mathrm{VC}_{\mathrm{T}}$ fit (Figure $9 \mathrm{~b}$ and Table 3), it must be born in mind that the ratio between the columnar aerosol optical depth and the horizontal extinction coefficient defines the scale height $\mathrm{H}$ (e.g., Horvath et al., 2002), which can be understood as the height a homogenous aerosol layer with given extinction coefficient would extend in order to have the given optical depth. The scale height factor makes the transformation from surface to columnar quantities. Besides, the slope of the fit between $\mathrm{PM}_{10}$ and $\mathrm{VC}_{\mathrm{T}}$ gives the ratio between two particle concentrations, one expressed by mass and the other one by volume, thus this slope is the ratio between aerosol particle density $\rho$ (in $\mathrm{g} \mathrm{cm}^{-3}$, in this case of desert dust particles) and the scale height $\mathrm{H}$. In this sense, the slope 
between the surface and columnar concentration can provide an estimate of the scale height or the particle density, depending on the known quantities.

Table 3 presents the linear fits between $\mathrm{PM}_{10}$ and $\mathrm{VC}_{\mathrm{T}}, \mathrm{PM}_{2.5}$ and $\mathrm{VC}_{\mathrm{F}}$, and $\mathrm{PM}_{2.5-10}$ and $\mathrm{VC}_{\mathrm{C}}$. These three linear fits exhibit correlations coefficients about 0.9 with the expected exceptions of the fine mode fit in the $\mathrm{VC}_{\mathrm{F}} / \mathrm{VC}_{\mathrm{T}} \leq 0.2$ category and the coarse mode fit in the $\mathrm{VC}_{\mathrm{F}} / \mathrm{VC}_{\mathrm{T}} \geq 0.45$ one. The $\mathrm{PM}_{10} \mathrm{Vs}_{\mathrm{VC}}$ exhibits increasing slopes as the fine mode fraction gains weight. The opposite is observed in the $\mathrm{PM}_{2.5}$ vs $\mathrm{VC}_{\mathrm{F}}$ fit. The slopes of these fits in Table 3 are in $\mathrm{g} \mathrm{m}^{-4}\left(\right.$ or $\left.\mu \mathrm{g} \mathrm{cm}^{-4}\right)$.

Table 3. Linear fits $(\mathrm{y}=\mathrm{b} \mathrm{x})$ for three different categories of $\mathrm{VC}_{\mathrm{F}} / \mathrm{VC}_{\mathrm{T}}$ ratio: $\left.\left.\mathrm{c} 1\right) \mathrm{VC}_{\mathrm{F}} / \mathrm{VC}_{\mathrm{T}} \leq 0.2, \mathrm{c} 2\right)$ $0.2<\mathrm{VC}_{\mathrm{F}} / \mathrm{VC}_{\mathrm{T}}<0.45$, and $\left.\mathrm{c} 3\right) \mathrm{VC}_{\mathrm{F}} / \mathrm{VC}_{\mathrm{T}} \geq 0.45$. The ' $\mathrm{StE}$ ', ' $\mathrm{R}$ ', and ' $\mathrm{N}$ ' are the standard error, correlation coefficient and number of data, respectively. The ' $\mathrm{H}$ ' column in the $\mathrm{PM}_{\mathrm{x}} \mathrm{Vs} \mathrm{VCx}$ fits is the corresponding scale height, assuming a particle density for crustal material of $2.2 \mathrm{~g} \mathrm{~cm}^{-3}$ (e.g., Sorribas et al., 2015). See text for units.

\begin{tabular}{|c|c|c|c|c|c|c|}
\hline Fit & $\begin{array}{l}\mathrm{VC}_{\mathrm{F}} / \mathrm{VC}_{\mathrm{T}} \\
\text { category }\end{array}$ & $\mathrm{b}$ & StE & $\mathrm{R}$ & $\mathrm{N}$ & $\mathrm{H}(\mathrm{m})$ \\
\hline \multirow{3}{*}{$\mathrm{AOD}$ vs $\mathrm{VC}_{\mathrm{T}}$} & $\mathrm{c} 1$ & 1.68 & 0.05 & 0.98 & 41 & - \\
\hline & $\mathrm{c} 2$ & 2.49 & 0.07 & 0.97 & 76 & - \\
\hline & c3 & 3.74 & 0.14 & 0.97 & 48 & - \\
\hline \multirow{3}{*}{$\mathrm{PM}_{10} \mathrm{vs} \mathrm{VC}_{\mathrm{T}}$} & $\mathrm{c} 1$ & 226 & 16 & 0.91 & 41 & 9725 \\
\hline & $\mathrm{c} 2$ & 236 & 12 & 0.92 & 76 & 9329 \\
\hline & $\mathrm{c} 3$ & 272 & 19 & 0.90 & 48 & 8080 \\
\hline \multirow{3}{*}{$\mathrm{PM}_{2.5}$ vs $\mathrm{VC}_{\mathrm{F}}$} & $\mathrm{c} 1$ & 620 & 64 & 0.84 & 41 & 3546 \\
\hline & $\mathrm{c} 2$ & 377 & 19 & 0.92 & 76 & 5843 \\
\hline & $\mathrm{c} 3$ & 309 & 21 & 0.91 & 48 & 7117 \\
\hline \multirow{3}{*}{$\mathrm{PM}_{2.5-10} \mathrm{vs} \mathrm{VC}_{\mathrm{C}}$} & $\mathrm{c} 1$ & 172 & 13 & 0.91 & 41 & 12781 \\
\hline & $\mathrm{c} 2$ & 163 & 10 & 0.88 & 76 & 13517 \\
\hline & c3 & 217 & 25 & 0.79 & 48 & 10157 \\
\hline \multirow{3}{*}{ AOD vs $\mathrm{PM}_{10}$} & $\mathrm{c} 1$ & 0.0062 & 0.0005 & 0.89 & 41 & - \\
\hline & $\mathrm{c} 2$ & 0.0091 & 0.0005 & 0.92 & 76 & - \\
\hline & $\mathrm{c} 3$ & 0.0114 & 0.0008 & 0.90 & 48 & - \\
\hline \multirow{3}{*}{ AOD vs $\mathrm{PM}_{2.5}$} & $\mathrm{c} 1$ & 0.0184 & 0.0015 & 0.89 & 41 & - \\
\hline & $\mathrm{c} 2$ & 0.0169 & 0.0009 & 0.92 & 76 & - \\
\hline & $\mathrm{c} 3$ & 0.0186 & 0.0012 & 0.91 & 48 & - \\
\hline
\end{tabular}

If the assumption of crustal material having a density of $2.2 \mathrm{~g} \mathrm{~cm}^{-3}$ is considered (Wagner et al., 2009; Sorribas et al., 2015), the scale factors $\mathrm{H}$ obtained with the $\mathrm{PM}_{10} \mathrm{Vs}_{\mathrm{VC}}$ slope (shown in Table 3) 645 range between $\sim 8000$ and $\sim 10000 \mathrm{~m}$ depending on the $\mathrm{VC}_{\mathrm{F}} / \mathrm{VC}_{\mathrm{T}}$ interval. When fine particles are 646 analyzed $\left(\mathrm{PM}_{2.5} \mathrm{vs} \mathrm{VC}_{\mathrm{F}}\right.$ and $\mathrm{VC}_{\mathrm{F}} / \mathrm{VC}_{\mathrm{T}} \geq 0.45$ category) the scale factor is $\sim 7000 \mathrm{~m}$, assuming the same 
density (Sorribas et al., 2015),. Finally, for the coarse particles a larger scale height $\mathrm{H}$ around $13000 \mathrm{~m}$ is obtained for the categories $\mathrm{VC}_{\mathrm{F}} / \mathrm{VC}_{\mathrm{T}} \leq 0.2$ and $0.2<\mathrm{VC}_{\mathrm{F}} / \mathrm{VC}_{\mathrm{T}}<0.45$. All these large scale factors indicate that a relevant portion of dust is contained in high layers with limited impact on the extinction at the ground. When there is not impact of neither desert dust nor other high turbidity events, the scale height $\mathrm{H}$ takes a mean value about $2700 \mathrm{~m}$, which is in line with the results reported by Horvath et al. (2002) in two sites in Spain and Austria during short campaigns, who obtained values ranging from 3000 to $5000 \mathrm{~m}$.

With this information, the ratio between $\mathrm{AOD}$ and $\mathrm{PM}_{10}$ or $\mathrm{PM}_{2.5}$ can be understood as an efficiency factor, with units of $\mathrm{m}^{3} / \mathrm{g}$. Hence, analogously to the efficiency introduced at the surface by Waggoner et al. (1981), the $\mathrm{AOD} / \mathrm{PM}_{10}$ and $\mathrm{AOD} / \mathrm{PM}_{2.5}$ ratios represent the mass extinction efficiency for the whole atmospheric column. The slopes for AOD vs $\mathrm{PM}_{10}$ fits are strongly dependent on the $\mathrm{VC}_{\mathrm{F}} / \mathrm{VC}_{\mathrm{T}}$ category, meanwhile AOD vs $\mathrm{PM}_{2.5}$ presents similar slopes for the three intervals. If the AOD quantity is estimated from the surface $\mathrm{PM}_{10}$ concentrations, a high dispersion is expected during DD outbreaks although the right identification of the aerosol microphysical properties can help to reduce the uncertainty.

\subsection{Aerosol radiative properties during DD events}

One of the most relevant aerosol parameter related to the aerosol absorption is the single scattering albedo (SSA). In order to characterize this quantity during DD events, its spectral dependence is shown in Figure 10a. The SSA values indicate a less absorbing power when mineral dust aerosols are identified, since they increase compared to non-dusty days for all wavelengths. For instance, the SSA values for D type increases with respect to the non-dusty conditions: from 0.89 to 0.94 at $675 \mathrm{~nm}$ and from 0.85 to 0.94 at $1020 \mathrm{~nm}$. The curve for the all the DD episodes (D+MD curve, with a mean SSA about 0.92) is almost wavelength independent but still contains the fingerprint of the increasing values from the UV to near-infrared (NIR) range that characterizes the mineral dust aerosol (see the D type curve). The marked increase between 440 and $670 \mathrm{~nm}$ is found for Saharan dust (Dubovik et al., 2002; Kim et al., 2011; García et al., 2008; Eck et al., 2010; Toledano et al., 2011, Giles et al., 2013, among others) but also at various Spanish sites during desert dust events (Cachorro et al., 2008, 2010; Valenzuela et al., 2012). The less absorbing character of DD aerosol still remains when analyzing the MD type but SSA decreases with wavelength, similarly to the non-dusty days. In this case, the fine mode becomes more relevant and the difference between SSA for MD and non-DD event days is weaker (e.g., from 0.89 to 0.91 at $675 \mathrm{~nm}$ and from 0.85 to 0.89 at $1020 \mathrm{~nm}$ ). 


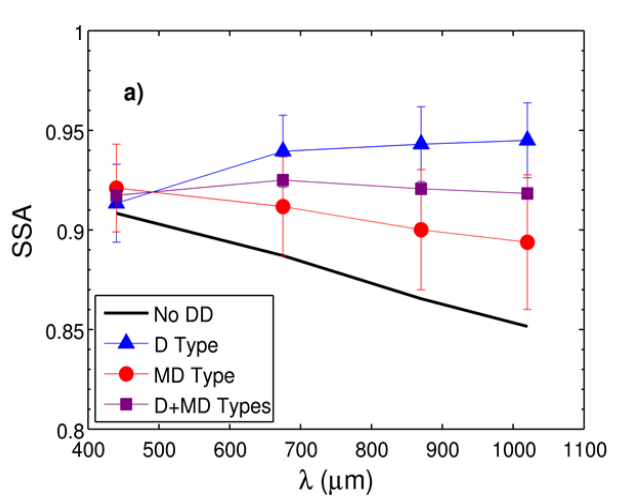

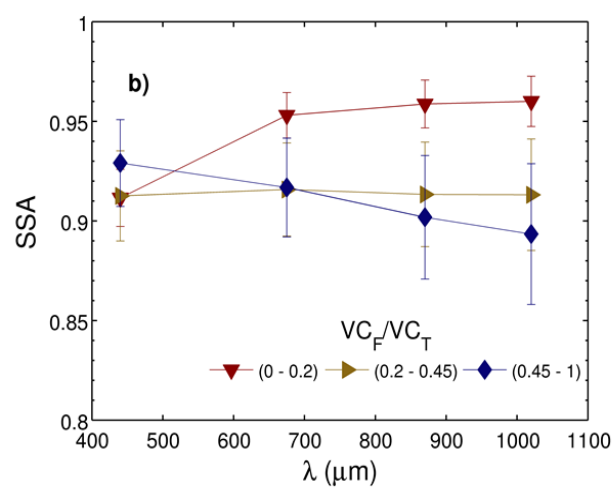

680

681

682

683

684

685

686

687

688

689

690

691

692

693

694

695

696

697

698

699

700

701

702

703

704

Figure 10. Spectral single scattering albedo: a) during DD and no DD episodes; b) for three different intervals of $\mathrm{VC}_{\mathrm{F}} / \mathrm{VC}_{\mathrm{T}}$.

As it was shown by Eck et al. (2010) at Ilorin site, the SSA displays a strong dependence on the fine mode volume fraction $\mathrm{VC}_{\mathrm{F}} / \mathrm{VC}_{\mathrm{T}}$, including its spectral behavior. Actually, the larger the fine mode volume fraction, the smaller the differences among the spectral SSA values; i.e., there is a notable SSA increase with wavelength for $\mathrm{VC}_{\mathrm{F}} / \mathrm{VC}_{\mathrm{T}}$ up to about 0.5 , while beyond this threshold there is no spectral change. In order to corroborate this behavior in our study area, Figure 10b shows the SSA spectral dependence in the three categories of $\mathrm{VC}_{\mathrm{F}} / \mathrm{VC}_{\mathrm{T}}$ for the $\mathrm{D}+\mathrm{MD}$ cases. Our results for $\mathrm{VC}_{\mathrm{F}} / \mathrm{VC}_{\mathrm{T}} \leq 0.2$ change from $\mathrm{SSA}=0.91$ at $440 \mathrm{~nm}$ to $\mathrm{SSA}=0.96$ at $1020 \mathrm{~nm}$, thus indicating the typical less absorbing power at longer wavelengths. The SSA curve for the intermediate range $\left(0.2<\mathrm{VC}_{\mathrm{F}} / \mathrm{VC}_{\mathrm{T}}<0.45\right)$ remains even, about 0.91 , meanwhile those conditions ruled by the fine mode $\left(\mathrm{VC}_{\mathrm{F}} / \mathrm{VC}_{\mathrm{T}} \geq 0.45\right)$ present a SSA decrease from 0.93 at $440 \mathrm{~nm}$ to 0.89 at $1020 \mathrm{~nm}$, pointing out most absorbing aerosols at longer wavelengths. Focusing on SSA at $440 \mathrm{~nm}$, very similar values are obtained for our three $\mathrm{VC}_{\mathrm{F}} / \mathrm{VC}_{\mathrm{T}}$ categories, which is in line with previous findings by Eck et al. (2010) for Kampur and XiangHe sites. This effect suggests that there is not any change on absorption power at 440nm among all the DD episodes in the inventory regardless the fine mode volume fraction. Another important intensive aerosol quantity related to the scattering processes is the asymmetry factor $(\mathrm{g}$ ) which gives information about the angular distribution of the light scattered by particles and spans from 0.6 to 0.8 for most of the aerosol types. Similarly to the SSA analysis, Figure 11 shows the g spectral dependence for different $\mathrm{DD}$ intrusion types and $\mathrm{VC}_{\mathrm{F}} / \mathrm{VC}_{\mathrm{T}}$ fractions. The non-dusty days are described by strong decreasing wavelength dependence from 0.71 at $440 \mathrm{~nm}$ to 0.6 at $1020 \mathrm{~nm}$. This decrease is softened for DD outbreaks (with larger values for the D event days, about 0.70-0.72), because $g$ increases with the particle size (Horvath et al. 1998; Cachorro et al., 2000). This feature is also noticeable when studying $g$ 
dependence on $\mathrm{VC}_{\mathrm{F}} / \mathrm{VC}_{\mathrm{T}}$ for the $\mathrm{D}+\mathrm{MD}$ cases. The categories of $\mathrm{VC}_{\mathrm{F}} / \mathrm{VC}_{\mathrm{T}} \leq 0.2$ and $0.2<\mathrm{VC}_{\mathrm{F}} / \mathrm{VC}_{\mathrm{T}}<$ 0.45 present similar values being $\mathrm{g}$ about $0.74-0.70$ at $440 \mathrm{~nm}$ and $0.72-0.67$ at $1020 \mathrm{~nm}$, respectively. Finally, for the fine-mode-dominated cases $\left(\mathrm{VC}_{\mathrm{F}} / \mathrm{VC}_{\mathrm{T}} \geq 0.45\right)$, g strongly decreases with wavelength (0.72-0.62). Dubovik et al. (2002) reported ranges of 0.69-0.65 and 0.73-0.71 at Solar Village and Cape Verde sites between 440 and $1020 \mathrm{~nm}$ for a desert dust and oceanic environment. In a DD characterization study in Granada (southern Iberian Peninsula) by Valenzuela et al. (2012), these authors obtained similar values for $\mathrm{g}$ spectral dependence, i.e. from 0.7 to 0.66 in the $440-1020 \mathrm{~nm}$ interval.
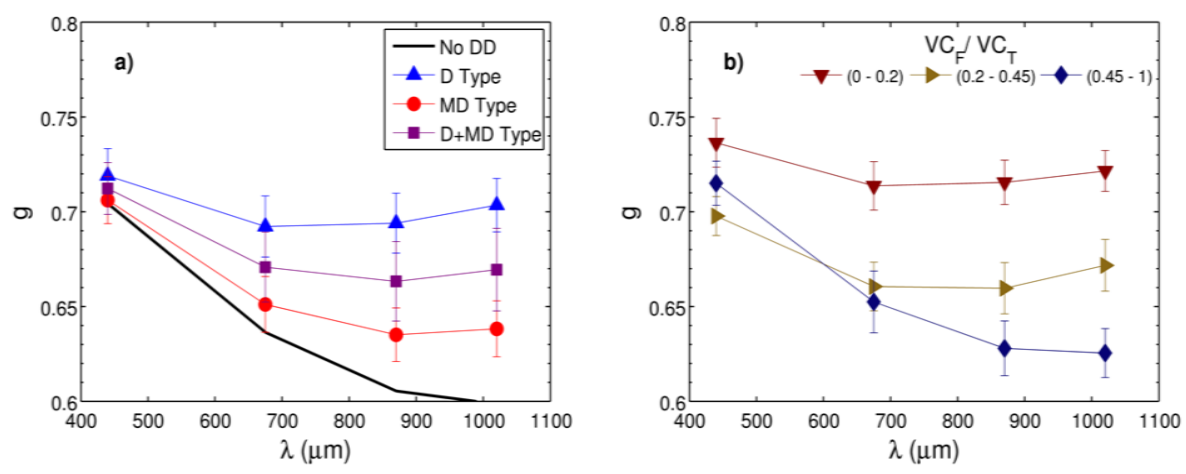

Figure 11. Asymmetry factor: a) during DD and no DD episodes; b) for the three different intervals of $\mathrm{VC}_{\mathrm{F}} / \mathrm{VC}_{\mathrm{T}}$.

\section{Conclusions}

The main statistics and characterization of aerosol size and load involving both surface and columnar properties of dusty days over north-central IP for a long-term period (2003-2014) is presented here. This study is based on a reliable inventory of DD intrusions obtained by the simultaneous usage of surface and columnar data (Cachorro et al., 2016). As a relevant result, the study reveals that most of the DD outbreaks contain desert dust aerosols mixed with other aerosol types, mainly anthropogenic pollution, biomass burning, or marine aerosols. Some of the aerosol properties studied are directly derived from measurements, like surface $\mathrm{PM}_{10}$ and $\mathrm{PM}_{2.5}$ and its ratio, or columnar data like AOD or $\mathrm{AE}$, and others are retrieved from a more complex inversion algorithm which requires sky radiance measurements, like the columnar particle size distribution and its derived parameters: effective radius, volume particle 
concentration, etc. Besides, optical parameters like the asymmetry factor and single scattering albedo are also considered.

This study highlights the relevance of the joint interpretation of surface and columnar aerosol data which includes certain relationships for DD episodes. Examples of these relationships are the total effective radius versus $\mathrm{AE}$, the fine mode volume fraction or the $\mathrm{PM}$ ratio, and the $\mathrm{VC}_{\mathrm{T}} \mathrm{Vs} \mathrm{AOD}$ or $\mathrm{PM}_{10}$, allowing the determination of the volume extinction factor or the scale height factor. For the first time, $\mathrm{PM}_{\mathrm{x}}$ measurements are linked to columnar inversion products during DD events for long term data, which is one of the novelties of the present study. The surface-columnar relationships are well established once the columnar aerosol DD properties are known. For instance, the slopes of the fits for each interval of $\mathrm{VC}_{\mathrm{F}} / \mathrm{VC}_{\mathrm{T}}$ range are obtained with high correlation coefficients.

Characterization aerosol studies are site-dependent due to the specific local conditions occurring over each site, but they are required to better understand how aerosol properties change over certain areas, particularly those relatively far away from the sources which receive frequent desert dust intrusions likely mixed, in greater or lesser extent, with other aerosol types. Our results are mostly in line with previous DD characterization studies carried out in the Mediterranean Basin and northern African surroundings. For the purest mineral dust events, all the aerosol properties present their typical values. The size (AE, PM ratio and total effective radius) and concentration (AOD, $\mathrm{PM}_{\mathrm{x}}$, and volume particle concentration) quantities exhibit significant correlation (in a greater or lesser extent). Furthermore, other microphysical and radiative properties such as non-sphericity and single scattering albedo are also congruent with previous results. Those cases showing fine mode volumen fraction below 0.2 represent $25 \%$ of the DD database with columnar inversion data. The remaining part ( $75 \%)$ highlights the large relevance of mixtures with mineral dust, which produce a wide range of aerosol properties. For instance, $\mathrm{VC}_{\mathrm{F}} / \mathrm{VC}_{\mathrm{T}}$ can be above 0.45 , sphericity fraction can overcome 0.7 , effective radii can reach $0.3 \mu \mathrm{m}$, and fair correlations $(\mathrm{R}<0.6)$ between $\mathrm{PM}_{10} / \mathrm{PM}_{2.5}$ and columnar volume concentrations can be found.

Analyzing the results of this study, some parameters seem to be more suitable than others to detect and classify desert dust aerosols, like $\mathrm{AE}$ and sphericity fraction. Defined ranges of these parameters allow the classification in different aerosol categories, as those given by $\mathrm{AE}$ or $\mathrm{VC}_{\mathrm{F}} / \mathrm{VC}_{\mathrm{T}}$. $\mathrm{A}$ threshold of $\mathrm{AE}=1$ is suitable for our area to distinguish between intrusions composed of aerosols with a strong prevailing DD character and those presenting a mixture of aerosols. This classification is corroborated by the non-sphericity and low values of $\mathrm{VC}_{\mathrm{F}} / \mathrm{VC}_{\mathrm{T}}$. The advantage of using $\mathrm{AE}$ quantity relies on its larger sampling compared to the other inversion products. 
Overall, the rapport between surface and columnar aerosol properties during DD intrusions here reported is relevant due to the different measurement techniques that are involved. The 12-years inventory is an extraordinary tool to investigate how DD fingerprints on aerosol properties change at both levels during different types of DD episodes. In particular, the columnar and surface retrievals about aerosol speciation during this kind of events can be a very interesting topic for further studies. Hence, this study is required to better understand their behavior along the whole Mediterranean Basin and can be used to validate DD forecast models or satellite DD products.

\section{Acknowledgements}

The authors are grateful to Spanish MINECO for the financial support of the FPI grant BES-2012051868, project CGL2012-33576, and “Juan de la Cierva - Incorporación” grant IJCI-2014-19477. The research leading to these results has received funding from the European Union under grant agreement Nr. 654109 [ACTRIS 2]. Thanks are due to EMEP (especially to MAGRAMA and AEMET) and AERONET-PHOTONS-RIMA staff for providing observations and for the maintenance of the networks. We also thank "Consejería de Fomento y Medio Ambiente" for their support to desert dust studies in Castilla y León region, as well as Consejería de Educación of Junta de Castilla y León for supporting the project (VA100U14).

\section{References}

Basart, S., Pérez, C., Cuevas, E., Baldasano, J.M., Gobbi, G.P., 2009. Aerosol characterization in Northern Africa, Northeastern Atlantic, mediterranean basin and middle east from direct-sun AERONET observations. Atmos. Chem. Phys. 9 (21), 8265-8282.

Bedareva, T.V., Sviridenkov, M.A., Zhuravleva, T.B., 2014. Retrieval of dust aerosol optical and microphysical properties from ground-based Sun-sky radiometer measurements in approximation of randomly oriented spheroids. J. Quan. Spectros. Rad. 146, 140-157. doi:10.1016/j.jqsrt.2014.05.006.

Bennouna, Y., Cachorro, V. E., Mateos, D., Burgos, M.A., Toledano, C., Torres, B., de Frutos, A.M., 2016. Long-term comparative study of columnar and surface mass concentration aerosol properties in a background environment. Atmos. Environ. 140, 261-272. 
Cabello, M., Orza, J. A. G., Barrero, M. A., Gordo, E., Berasaluce, A., Cantón, L., Dueñas, C., Fernández, M. C., Pérez, M., 2012. Spatial and temporal variation of the impact of an extreme Saharan dust event. J. Geophys. Res. 117 , D11204. doi:10.1029/2012JD017513.

Cachorro, V.E., Duran, P., Vergaz, R., de Frutos, A.M., 2000. Columnar physical and radiative properties of atmospheric aerosols in north central Spain. J. Geophys. Res.-Atmos. 105(D6), 7161- 7175.

Cachorro, V. E., Toledano, C., Prats, N., Sorribas, M., Mogo, S., Berjón, A., Torres, B., Rodrigo, R., de la Rosa, J., de Frutos, A.M., 2008. The strongest desert dust intrusion mixed with smoke over the Iberian Peninsula registered with Sun photometry. J. Geophys. Res. 113, D14S04. doi:10.1029/2007JD009582.

Cachorro, V. E., Toledano, C., Antón, M., Berjón, A., de Frutos, A.M., Vilaplana, J. M., Arola, A., Krotkov, N.A., 2010. Comparison of UV irradiances from Aura/Ozone Monitoring Instrument (OMI) with Brewer measurements at El Arenosillo (Spain) - Part 2: Analysis of site aerosol influence. Atmos. Chem. Phys. 10, 11867-11880. doi:10.5194/acp10-11867-2010.

Cachorro, V. E., Burgos, M.A., Mateos, D., Toledano, C., Bennouna, Y., Torres, B., de Frutos, A.M., Herguedas, A., 2016. Inventory of African desert dust events in the North-central Iberian Peninsula in 2003-2014 based on Sun photometer and PMx data. Atmos Chem Phys. 16, 8227-8248. doi:10.5194/acp-16-8227-2016.

Cuesta, J., Edouart, D., Mimouni, M., Flamant, P. H., Loth, C., Gibert, F., Marnas, F., Bouklila, A., Kharef, M., Ouchene, B., Kadi, M., Flamant, C., 2008. Multiplatform observations of the seasonal evolution of the Saharan atmospheric boundary layer in Tamanrasset, Algeria, in the framework of the African Monsoon Multidisciplinary Analysis field campaign conducted in 2006. J. Geophys. Res.-Atmos. 113, D00C07. doi:10.1029/2007jd009417.

Di Biagio, C., di Sarra, A., Meloni, D., 2010. Large atmospheric shortwave radiative forcing by Mediterranean aerosols derived from simultaneous ground-based and spaceborne observations and dependence on the aerosol type and single scattering albedo. J. Geophys. Res. 115, D10209. doi:10.1029/2009JD012697.

Dubovik, O., King, M.D., 2000. A flexible inversion algorithm for retrieval of aerosol optical properties from Sun and sky radiance measurements. J. Geophys. Res. 105, D16, 20673-20696.

Dubovik, O., Holben, B., Eck, T.F., Smirnov, A., Kaufman, Y.J., King, M.D., Tanre, D., Slutsker, I., 2002. Variability of absorption and optical properties of key aerosol types observed in worldwide locations. J. Atmos. Sci. 59, 590-608.

Dubovik, O., Sinyuk, A., Lapyonok, T., Holben, B.N., Mishchenko, M., Yang, P., Eck, T.F., Volten, H., Munoz, O., Veihelmann, B., van der Zande, W.J., Leon, J.F., Sorokin, M., Slutsker, I., 2006. Application of spheroid models to account for aerosol particle nonsphericity in remote sensing of desert dust. J. Geophys. Res.-Atmos. 111 (D11), 21562202. doi:10.1029/2005JD006619.

Eck, T.F., Holben, B.N., Dubovik, O., Smirnov, A., Goloub, P., Chen, H.B., Chatenet, B., Gomes, L., Zhang, X.Y., Tsay, S.C., Ji, Q., Giles, D., Slutsker, I., 2005. Columnar aerosol optical properties at AERONET sites in central eastern Asia and aerosol transport to the tropical mid-Pacific. J. Geophys. Res. 110, D06202.

Eck, T.F., Holben, B.N., Reid, J.S., Sinyuk, A., Dubovik, O., Smirnov, A., Giles, D., O'Neill, N.T., Tsay, S.-C., Ji, Q., Al Mandoos, A., Ramzan Khan, M., Reid, E.A., Schafer, J.S., Sorokine, M., Newcomb,W., Slutsker, I., 2008. Spatial and 
temporal variability of column-integrated aerosol optical properties in the southern Arabian Gulf and United Arab Emirates in summer. J. Geophys. Res. 113 (D01204).

Eck, T. F., Holben, B. N., Sinyuk, A., Pinker, R. T., Goloub, P., Chen, H,. Chatenet, B., Li, Z., Singh, R. P., Tripathi, S. N., Reid, J. S., Giles, D. M., Dubovik, O., O’Neill, N. T., Smirnov, A., Wang, P., Xia, X., 2010. Climatological aspects of the optical properties of fine/coarse mode aerosol mixtures. J. Geophys. Res. 115, D19205. doi:10.1029/2010JD014002.

Escudero, M., Castillo, S., Querol, X., Avila, A., Alarcón, M., Viana, M. M., Alastuey, A., Cuevas, E., Rodríguez S., 2005. Wet and dry African dust episodes over eastern Spain. J. Geophys. Res. 110, D18S08. doi:10.1029/2004JD004731.

Escudero, M., Querol, X., Pey, J., Alastuey, A., Pérez, N., Ferreira, F., Alonso, S., Cuevas, E., 2007. A methodology for the quantification of the net African dust load in air quality monitoring networks. Atmos. Environ. 41(26), 5516-5524. doi: 10.1016/j.atmosenv.2007.04.047.

Estellés, V., Martínez-Lozano, J. A., Utrillas, M. P., 2007. Influence of air mas history on the columnar aerosol properties at Valencia, Spain. J. Geophys. Res. 112, D15211. doi:10.1029/2007JD008593.

Fraser, R. S., Kaufman, Y. J., Mahoney, R. L., 1984. Satellite measurements of aerosol mass and transport. Atmos. Environ., $18,2577-2584$.

García, O. E., Diaz, A.M., Exposito, F.J., Diaz, J.P., Dubovik, O., Dubuisson, P., Roger, J.-C., Eck, T.F., Sinyuk, A., Derimian, Y., Dutton, E.G., Schafer, J.S., Holben, B.N., Gacria, C.A., 2008. Validation of AERONET estimates of atmospheric solar surface fluxes and aerosol radiative forcing by ground-based broadband measurements. J. Geophys. Res. 113, D21207. 10.1029/2008JD010211.

Giles, D. M., Holben, B. N., Eck, T. F., Sinyuk, A., Smirnov, A., Slutsker, I., Dickerson, R. R., Thompson, A. M., Schafer, J. S., 2012. An analysis of AERONET aerosol absorption properties and classifications representative of aerosol source regions. J. Geophys. Res. 117, D17203. doi:10.1029/2012JD018127.

Gkikas, A., Hatzianastassiou, N., Mihalopoulos, N., Katsoulis, V., Kazadzis, S., Pey, J., Querol, X., Torres, O., 2013. The regime of intense desert dust episodes in the Mediterranean based on contemporary satellite observations and ground measurements. Atmos. Chem. Phys., 13(23), 12135-12154. doi:10.5194/acp-13-12135-2013.

Gkikas, A., Hatzianastassiou, N., Mihalopoulos, N., Torres, O., 2016. Characterization of aerosol episodes in the greater Mediterranean Sea area from satellite observations (2000-2007). Atmos. Environ. 118, 286-304. doi: 10.1016/j.atmosenv.2015.11.056.

Gonzi, S., Baumgartner, D., Putz, E., 2002. Aerosol Climatology and Optical Properties of Key Aerosol Types Observed in Europe, IGAM/UG Technical Report for EU No. 1/2002 EDUCE, http://www.uni-graz.at/en/igam1www gonzi educe b.pdf

Goudie, A.S., Middleton, N.J., 2001. Saharan dust storms: nature and consequences. Earth-Sci. Rev. 56, 179-204, http://dx.doi.org/10.1016/S0012-8252(01)00067-8. 
Guirado, C., Cuevas, E., Cachorro, V. E., Toledano, C., Alonso-Pérez, S., Bustos, J. J., Basart, S., Romero, P. M., Camino, C., Mimouni, M.. Zeudmi, L.. Goloub, P., Baldasano, J. M., de Frutos, A. M., 2014. Aerosol characterization at the Saharan AERONET site Tamanrasset. Atmos. Chem. Phys. 14(21), 11753-11773. doi:10.5194/acp-14-11753-2014.

Holben, B. N., Eck,, Slutsker, I., Tanré, D., Buis, J. P., Setzer, A., Vermote, E., Smirnov, A., 1998. AERONET - A federated instrument network and data archive for aerosol characterization. Remote. Sens. Environ. 66(1), 1-16. doi: 10.1016/S0034-4257(98)00031-5.

Holben, B., Eck, T., Slutsker, I., Smirnov, A., Sinyuk, A., Schafer, J., Giles, D., Dubovik, O., 2006. AERONET's version 2.0 quality assurance criteria, Remote Sensing of the Atmosphere and Clouds, Proc. SPIE 6408, 64080Q, doi:10.1117/12.706524, 2006.

Horvath, H., 1998. Influence of Atmospheric Aerosols upon the Global Radiation Balance. Atmospheric Particles. John Wiley \& Sons Ltd..

Horvath, H., Alados Arboledas, L., Olmo, F. J., Jovanovic, O., Gangl, M., Kaller, W., Sánchez, C., Sauerzopf, H., Seidl, S., 2002. Optical characteristics of the aerosol in Spain and Austria and its effect on radiative forcing, J. Geophys. Res. 107(D19), 4386. doi:10.1029/2001JD001472.

Kacenelenbogen, M., Léon, J.F., Chiapello, I., Tanré, D.. 2006. Characterization of aerosol pollution events in France using ground-based and POLDER-2 satellite data. Atmos. Chem. Phys. 6, 4843 - 4849.

Kaufman, Y. J., Koren, I. Remer, L. A., Tanré, D., Ginoux, P., Fan, S., 2005. Dust transport and deposition observed from the Terra-Moderate Resolution Imaging Spectroradiometer (MODIS) spacecraft over the Atlantic Ocean. J. Geophys. Res. 110, D10S12. doi:10.1029/2003JD004436.

Kim, D., Chin, M., Yu, H., Eck, T.F., Sinyuk, A., Smirnov, A., Holben, B.N., 2011. Dust optical properties over North Africa and Arabian Peninsula derived from the AERONET dataset. Atmos. Chem. Phys. 11, $10733-10741$. http://dx.doi.org/10.5194/acp-11-10733-2011.

Knippertz, P., and Stuut, J.-B. W., 2014. Chapter 1 Introduction. In: Knippertz P, Stuut J-BW (eds) Mineral dust: a key player in the earth system. Springer, New York, 1-14, doi:10.1007/978-94-017-8978-3.

Kokhanovsky, A. A., Prikhach, A. S., Katsev, I. L., Zege, E. P., 2009. Determination of particulate matter vertical columns using satellite observations. Atmos. Meas. Tech. 2, 327-335. doi:10.5194/amt-2-327-2009.

Liu, Y., Park, R.J., Jacob, D.J., Li, Q., Kilaru, V., Sarnat, J.A., 2004. Mapping annual mean ground-level PM 2.5 concentrations using Multiangle Imaging Spectroradiometer aerosol optical thickness over the contiguous United States. J. Geophys. Res. D: Atmospheres, 109 (22), 1-10.

Mallet, M., Dubovik, O., Nabat, P., Dulac, F., Kahn, R., Sciare, J., Paronis, D., Léon, J.F., 2013. Absorption properties of Mediterranean aerosols obtained from multi-year ground-based remote sensing observations. Atmos. Chem. Phys., 13 (18), 9195-9210. 
Mateos, D., Antón, M., Toledano, C., Cachorro, V. E., Alados-Arboledas, L., Sorribas, M., Baldasano, J. M., 2014. Aerosol radiative effects in the ultraviolet, visible, and near-infrared spectral ranges using long-term aerosol data series over the Iberian Peninsula. Atmos. Chem. Phys. 14(24), 13497-13514. doi:10.5194/acp-14-13497-2014.

Mateos, D., Cachorro, V. E., Toledano, C., Burgos, M. A., Bennouna, Y., Torres, B., Fuertes, D., González, R., Guirado, C., Calle, A., de Frutos, A. M. 2015. Columnar and surface aerosol load over the Iberian Peninsula establishing annual cycles, trends, and relationships in five geographical sectors. Sci. Total Environ. 518-519, 378-392, doi:10.1016/j.scitotenv.2015.03.002.

Meloni, D., di Sarra, A., Pace, G., Monteleone, F., 2006. Optical properties of aerosols over the central Mediterranean. 2. Determination of single scattering albedo at two wavelengths for different aerosol types. Atmos. Chem. Phys. 6, $715 \mathrm{e} 727$.

Meloni, D., di Sarra, A., Biavati, G., DeLuisi, J.J., Monteleone, F., Pace, G., Piacentino, S., Sferlazzo, D.M., 2007. Seasonal behavior of Saharan dust events at the Mediterranean island of Lampedusa in the period 1999-2005. Atmos. Environ. 41, 14, 3041-3056. http://dx.doi.org/10.1016/j.atmosenv.2006.12.001 .

Obregón, M.A., Serrano, A., Cancillo, M.L., Cachorro, V.E., Toledano, C., 2015. Aerosol radiometric properties at Western Spain (Cáceres station). Int. J. Climatol. 35 (6), 981-990. doi: 10.1002/joc.4031.

Pace, G., di Sarra, A., Meloni, D., Piacentino, S., and Chamard, P., (2006). Aerosol optical properties at Lampedusa (Central Mediterranean). 1. Influence of transport and identification of different aerosol types. Atmos. Chem. Phys. 6, 697-713, doi:10.5194/acp-6-697-2006.

Pérez, L., Tobías, A., Querol, X., Pey, J., Alastuey, A., Díaz, J., Sunyer, J., 2012. Saharan dust, particulate matter and causespecific mortality: A case-crossover study in Barcelona (Spain). Environ. Int. 48, 150-155. doi: 10.1016/j.envint.2012.07.001.

Pey, J., Querol, X., Alastuey, A., Forastiere, F., Stafoggia, M., 2013. African dust outbreaks over the Mediterranean Basin during 2001-2011: $\mathrm{PM}_{10}$ concentrations, phenomenology and trends, and its relation with synoptic and mesoscale meteorology. Atmos. Chem. Phys. 13(3), 1395-1410. doi:10.5194/acp-13-1395-2013.

Prats, N., Cachorro, V.E., Sorribas, M., Mogo, S., Berjón, A., Toledano, C., de Frutos, A.M., de la Rosa, J., Laulainen, N., de la Morena, B.A., 2008. Columnar aerosol properties during "El Arenosillo 2004 summer campaign”. Atmos. Environ. 42, 2643-2653, doi:10.1016/j.atmosenv.2007.07.041.

Prats, N., Cachorro, V.E., Berjón, A., Toledano, C., de Frutos, A.M., 2011. Column-integrated aerosol microphysical properties from an AERONET Sun photometer over southwestern Spain. Atmos. Chem. Phys. 11: 12535-12547, doi: 10.5194/acp-11-12535-2011.

Prospero, J. M., Ginoux, P., Torres, O., Nicholson, S. E., Gill, T. E., 2002. Environmental characterization of global sources of atmospheric soil dust identified with the nimbus 7 total ozone mapping spectrometer (TOMS) absorbing aerosol product. Rev. Geophys. 40(1), 2-1--2-31. doi:10.1029/2000RG000095. 
Querol, X., Pey, J., Pandolfi, M., Alastuey, A., Cusack, M., Pérez, N., Moreno, T., Kleanthous, S., 2009. African dust contributions to mean ambient $\mathrm{PM}_{10}$ mass-levels across the Mediterranean Basin. Atmos. Environ. 43(28), 4266-4277, doi: 10.1016/j.atmosenv.2009.06.013.

Querol, X., Alastuey, A., Pandolfi, M., Reche, C., Pérez, N., Minguillón, M. C., Moreno, T., Viana, M., Escudero, M., Orio, A., Pallarés, M., Reina, F., 2014. 2001-2012 trends on air quality in Spain, Sci. Total Environ. 490, 957-969, doi:10.1016/j.scitotenv.2014.05.074.

Reyes, M., Díaz, J., Tobias, A., Montero, J.C., Linares, C., 2014. Impact of Saharan dust particles on hospital admissions in Madrid (Spain). Int J Environ Health Res. 24(1):63-72. doi: 10.1080/09603123.2013.782604.

Rodríguez, E., Toledano, C., Cachorro, V. E., Ortiz, P., Stebel, K., Berjón, A., Blindheim, S., Gausa, M. de Frutos, A. M. 2012. Aerosol characterization at the sub-Arctic site Andenes $\left(69^{\circ} \mathrm{N}, 16^{\circ} \mathrm{E}\right)$, by the analysis of columnar optical properties. Q.J.R. Meteorol. Soc., 138: 471-482. doi: 10.1002/qj.921.

Rohen, G. J., von Hoyningen-Huene, W., Kokhanovsky, A., Dinter, T., Vountas, M., and Burrows, J. P., 2011. Retrieval of aerosol mass load $\left(\mathrm{PM}_{10}\right)$ from MERIS/Envisat top of atmosphere spectral reflectance measurements over Germany, Atmos. Meas. Tech. 4, 523-534. doi:10.5194/amt-4-523-2011.

Ryder, C. L., Highwood, E. J., Lai, T. M., Sodemann, H., Marsham, J. H., 2013. Impact of atmospheric transport on the evolution of microphysical and optical properties of Saharan dust. Geophys. Res. Lett. 40, 2433-2438, doi:10.1002/Grl.50482.

Salvador, P., Artiñano, B., Molero, F., Viana, M., Pey, J., Alastuey, A., Querol, X., 2013. African Dust Contribution to Ambient Aerosol Levels Across Central Spain: Characterization of Long-Range Transport Episodes of Desert Dust. Atmos. Res. 127, 117-129. doi:10.1016/j.atmosres.2011.12.011.

Salvador, P., Alonso-Pérez, S., Pey, J., Artíñano, B., de Bustos, J.J., Alastuey, A., Querol, X., 2014. African dust outbreaks over the western Mediterranean Basin: 11-year characterization of atmospheric circulation patterns and dust source areas. Atmos. Chem. Phys. 14, 6759-6775, doi:10.5194/acp-14-6759-2014.

Silva A, Bugalho M, Costa MJ, von Hoyningen-Huene V, Shmidt T,Heintzenberg J, Henning S., 2002. Aerosol optical properties fromcolumnar data during the second Aerosol Characterization Experiment on the south coast of Portugal. J. Geophys. Res. 107(D22), 4642,.doi:10.1029/2002JD002196.

Tafuro, A.M., Barnaba, F., de Tomasi, F., Perrone, M.R., Gobbi, G.P., 2006. Saharan dust particle properties over the central Mediterranean. Atmos. Res. 81-1, 67-93.

Taylor, M., Kazadzis, S., Amiridis, V., Kahn, R.A., 2015. Global aerosol mixtures and their multiyear and seasonal characteristics. Atmos. Environ. 116, 112-129.

Toledano, C., Cachorro, V. E., de Frutos, A. M., Sorribas, M., Prats, N., 2007. Inventory of African Desert Dust Events Over the Southwestern Iberian Peninsula in 2000-2005 with an AERONET Cimel Sun Photometer. J. Geophys. Res., 112(21), D21201. doi:10.1029/2006JD008307. 
Toledano, C., Wiegner, M., Groß, S., Freudenthaler, V., Gasteiger, J., Müller, D., Müller, T., Schladitz, A., Weinzierl, B., Torres, B., and O’Neill, N. T., 2011. Optical properties of aerosol mixtures derived from sun-sky radiometry during SAMUM-2. Tellus B. 63, 635-648.

Toledano, C., Cachorro, V.E., Gausa, M., Stebel, K., Aaltonen, V., Berjón, A., Ortiz de Galisteo, J.P., de Frutos, A.M., Bennouna, Y., Blindheim, S., Myhre, C.L., Zibordi, G., Wehrli, C., Kratzer, S., Hakansson, B., Carlund, T., de Leeuw, G., Herber, A., Torres, B., 2012. Overview of sun photometer measurements of aerosol properties in Scandinavia and Svalbard. Atmos. Env. 52, 18-28, doi:10.1016/j.atmosenv.2011.10.022.

Torres, B., Dubovik, O., Toledano, C., Berjon, A., Cachorro, V. E., Lapyonok, T., Litvinov, P., and Goloub, P., 2014. Sensitivity of aerosol retrieval to geometrical configuration of ground-based sun/sky radiometer observations. Atmos. Chem. Phys. 14, 847-875. doi:10.5194/acp-14-847-2014.

Valenzuela, A., Olmo, F. J., Lyamani, H., Antón, M., Quirantes, A., Alados-Arboledas, L. 2012. Aerosol radiative forcing during African desert dust events (2005-2010) over Southeastern Spain. Atmos. Chem. Phys. 12(21), 10331-10351, doi:10.5194/acp-12-10331-2012.

Valenzuela, A., Olmo, F.J., Lyamani, H., Granados-Muñoz, M.J., Antón, M., Guerrero-Rascado, J.L., Quirantes, A., Toledano, C., Perez-Ramírez, D., Alados-Arboledas, L., 2014. Aerosol transport over the western Mediterranean basin: Evidence of the contribution of fine particles to desert dust plumes over Alborán Island. J. Geophys. Res.-Atmos. 119 (24), 14028-14044. doi: 10.1002/2014JD022044.

Viana, M., Pey, J., Querol, X., Alastuey, A., de Leeuw, F., Lükewille, A., 2014. Natural Sources of Atmospheric Aerosols Influencing Air Quality Across Europe. Sci. Total Environ. 472, 825-833. doi:10.1016/j.scitotenv.2013.11.140.

Waggoner, A. P., Weiss, R., Ahlquist, N., Covert, D., Will, S., and Charlson, R., 1981. Optical characteristics of atmospheric aerosols. Atmos. Environ. 15, 1891-1909.

Yannopoulos, S.I., Lyberatos, G., Theodossiou, N., Li, W., Valipour, M., Tamburrino, A., Angelakis, A.N., 2015. Evolution of Water Lifting Devices (Pumps) over the Centuries Worldwide. Water 7, 5031-5060, doi:10.3390/w7095031. 

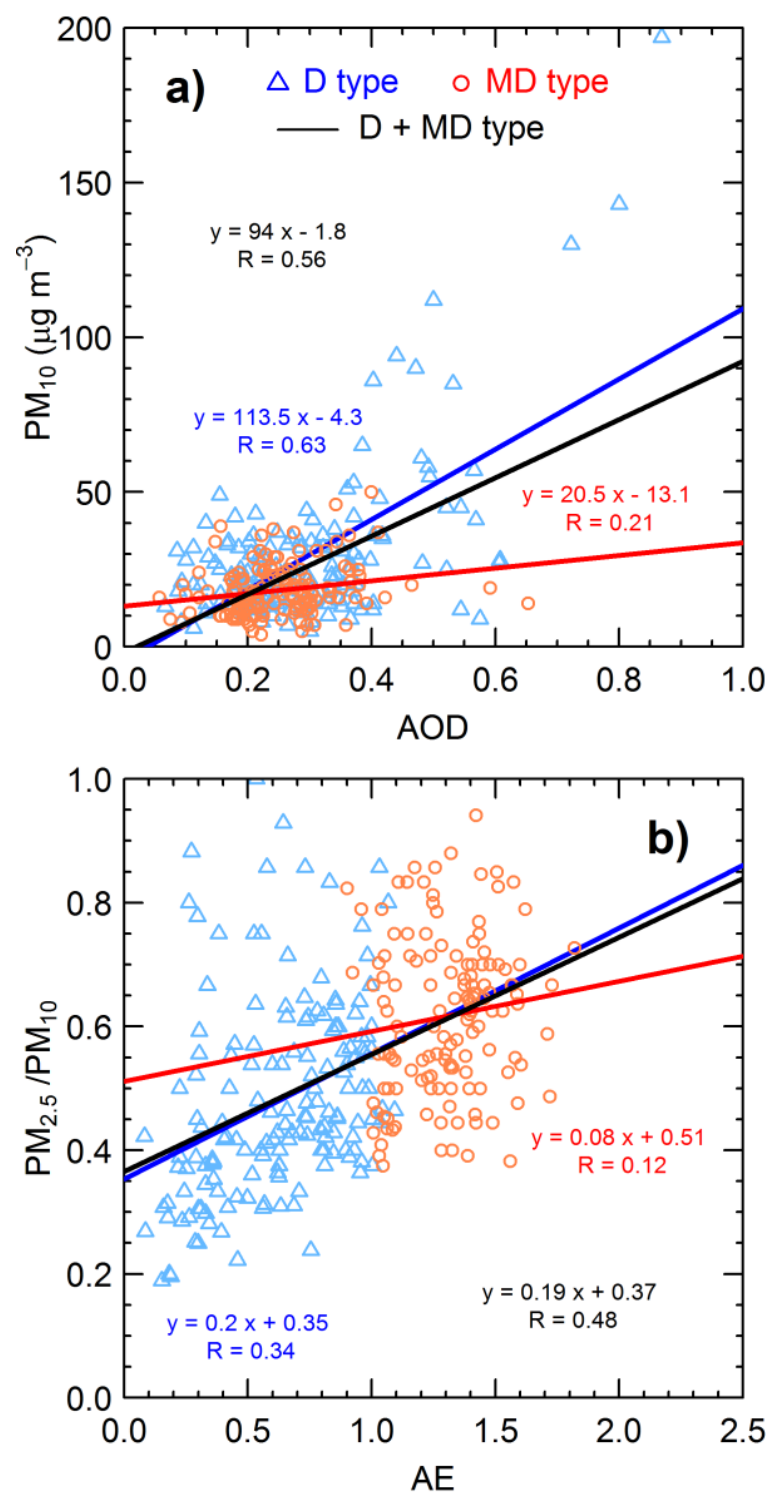

Figure S1. $\mathrm{PM}_{10}$-AOD (a) and $\mathrm{PM}_{2.5} / \mathrm{PM}_{10}-\mathrm{AE}$

(b) scatterplots for D (blue triangles) and MD (red 983 circles) event days. Solid lines are the linear fits, being the black one the fit for the total DD database. 